\title{
Dutch Disease Effects in the Azerbaijan Economy: Results of Multivariate Linear Ordinary Least Squares (OLS) Estimations
}

\author{
Ibrahim Niftiyev
}

\author{
University of Szeged, \\ Kálvária sgt. 1., 6722, Szeged, Hungary. \\ E-mail: ibrahimniftiyev@gmail.com
}

\begin{abstract}
This paper investigates the increased role of extractive industry, particularly oil and gas, within the Dutch disease model between 2000-2018 in the Azerbaijan economy. Dutch disease phenomenon befalls when the national economy produces and exports a single commodity or a particular sector becomes the booming sector. Increased exports of particular goods and spendings of the accumulated mineral revenue appreciate the national currency, decreasing the competitiveness and thus the production or export volume of the non-booming sectors. Azerbaijan is an oil and gas-rich country which naturally actualizes the existence of Dutch disease syndrome. Therefore, the purpose of this research is to separately reveal the Dutch disease effects of resource movement and spending effects based on the theoretical framework constructed from the core theory. The paper contains a comprehensive literature review and overall macroeconomic screening of the Azerbaijan economy to describe the preconditions of Dutch disease. Then, the study employs 42 multivariate linear ordinary least squares (OLS) estimations. The estimated models illustrate the presence of indirect de-industrialization (one form of resource movement effect) and the spending effect of the Dutch disease hypothesis. However, the paper does not find a direct negative influence of booming sectors on aggregated lagging (i.e., manufacturing and agriculture) and non-tradable sectors (services). Moreover, variables such as oil price growth rates, real effective exchange rate (REER), nominal effective exchange rate (NEER), and economic crisis periods failed to significantly explain the employment and real wages dynamics. However, these variables described certain influence channels in output and returns on capital growth rates. This paper sheds light on the interconnections between the Azerbaijan economy's labor resources, government spending, and monetary channels. These interconnections indicate that the Dutch disease hypothesis holds true for Azerbaijan. Of the estimated
\end{abstract}

Ibrahim Niftiyev - PhD candidate and researcher at the Institute of Finance and International Economic Relations, Doctoral School in Economics; Center for Studies on European Economy (AIM) - Azerbaijan State University of Economics (UNEC).

The article was received: 10.08.2020/The article is accepted for publication: 08.04.2021. 
OLS coefficients, $90.5 \%$ were highly stable, which suggests that the results are reliable. This study mainly tests the general theoretical expectations of the original Dutch disease model and presents a common ground to conceptualize the possible harmful effects of the booming oil and gas sectors in Azerbaijan. Any causal derivations should be handled carefully.

Key words: resource abundance; Azerbaijan economy; oil and gas sector; Dutch disease; resource movement effect; spending effect; real effective exchange rate; booming sector; OLS regression.

JEL Classification: C30, F41, F43, Q32, Q33.

DOI: $10.17323 / 1813-8691-2021-25-2-309-346$

For citation: Niftiyev I. Dutch Disease Effects in the Azerbaijan Economy: Results of Multivariate Linear Ordinary Least Squares (OLS) Estimations. HSE Economic Journal. 2021; 25(2): 309-346.

\section{Introduction}

Azerbaijan is the most resource-driven country in the post-Soviet region [World Bank, 2020a]. It is among the top 15 oil-dependent countries in the world [Czech, 2018] as measured by oil rents ${ }^{1}$ as share of gross domestic product (GDP). Azerbaijan's oil rents as share of GDP rapidly increased starting from 2001 (22.5\%) and peaked at 39.6\% in 2006. Oil rents in other resourcerich post-Soviet countries such as Russia, Kazakhstan, and Turkmenistan never exceeded Azerbaijan's [World Bank, 2020a]. Azerbaijan's exports mainly included oil and petroleum products. While value-added in the national economy mostly occurred in the mining sector, manufacturing and agriculture sectors underwent gradual contractions. Tertiary sectors expanded because of the government expenditures sourcing from the accumulated mineral revenue. Therefore, almost all large infrastructure or transportation projects served to fulfill the extractive industry's demands, particularly new oil and gas projects.

The description of the economic structure illustrates the major role of mineral resources and its multiplicator effect (government spending sourcing from oil revenue, new extractive projects, etc.) A mineral resource boom may boost the economic growth of a small and transition country like Azerbaijan. However, the risks associated by crude oil exports or minimally processed mineral exports can pose challenges in the form of slower growth. These phenomena are known as the natural resource curse [Auty, 1993; Sachs, Warner, 2001] and Dutch disease [Corden, Neary, 1982; Corden, 1984].

The core model of Dutch disease suggests that in a three-sector economy (booming, lagging, and non-tradable sectors) [Corden, Neary, 1982], the higher disposable income resulting from natural resource discoveries, capital inflow, aid, or remittances can increase the aggregate demand. Accordingly, government or private agents tend to spend more, given a positive income elasticity, and therefore higher expenditures increase the price of non-tradable sectors (spending effect).

${ }^{1}$ According to the World Bank (2020), «Oil rents are the difference between the value of crude oil production at world prices and total costs of production». 
In this case, real exchange rate appreciation (REER) occurs because of the relative price of nontradable sectors over the tradable sectors' rise (the price of tradable sectors like manufacturing or agriculture are exogenously given and they stay stable under the core model) [Brahmbhatt et al., 2010]. In addition, resource sectors may expand at the expense of non-resource sectors because booming sectors can attract labor and capital away from the rest of the economy, decreasing the latter sectors' output and employment (also known as the resource movement effect) [Fardmanesh, 1991].

Increased crude oil exports and favorable oil prices caused the Azerbaijan economy to experience rapid growth of GDP and GDP per capita during the oil revenue boom period of 20082011, as measured by the revenue of the State Oil Fund of The Republic of Azerbaijan (SOFAZ). For instance, the median value of GDP in current prices between 1990-2000 was 4,446 billion USD. During and after the oil booming period (until the commodity price slowdowns), that median value reached 38,671 billion USD [World Bank, 2020b]. In 2014, GDP per capita in current USD was 12 times higher in 2000, when GDP per capita was \$655.1 [World Bank, 2020c]. Moreover, GDP per capita purchasing power parity (PPP) (current international \$) was $\$ 3,836.6$ in 2001 but gradually reached $\$ 14,926.64$ in 2011 and lowered to $\$ 14,543.20$ in 2018 [World Bank, 2020d].

Despite the achievements of the Azerbaijan economy, it has been described as having the «natural resource curse» [O'lear, 2007; Gojayev, 2010; Gasimov, 2014]. This term was coined by Auty (1993) and empirically tested by Sachs and Warner (1995). The curse describes a situation when resource-abundant countries perform worse than resource-poor countries in terms of economic growth and well-being. Similarly, the existence and documentation of Dutch disease effects in the Azerbaijan economy have gained attention during the last 20 years [Gahramanov, Fan, 2002; Hasanov, 2013; Zulfugarov, Neuenkirch, 2019; Niftiyev, 2020]. Nevertheless, Bayramov and Conway (2010), Şanlısoy and Ekinci (2019), and others questioned the existence of Dutch disease effects in the Azerbaijan economy.

Dutch disease poses a significant risk. If the manufacturing and agriculture sectors shrink their share of the output and net exports (de-industrialization or de-agriculturalization) due to exchange rate appreciation, there will be a decreased capacity to utilize the potential opportunities (innovative technologies, industrial spillovers, technical knowledge, etc.) to benefit from the learning-by-doing process [Magud, Sosa, 2013]. Academics have argued that manufacturing and agriculture ensure growth and that any crowding-out might harm the economy in the long-term [Krugman, 1987; Matsuyama, 1992; Lucas, 1993; Hausmann et al., 2007].

The research question of the paper is as follows: does the extractive industry have any negative impact on non-resource sectors and economic growth in Azerbaijan, where that impact is predicted by the Dutch disease model? The purpose of this study is to track the possible channels of the Dutch disease syndrome based on the constructed theoretical framework that stems from the core model of the Dutch disease hypothesis as authored by Corden and Neary (1982) and Corden (1984). The main methodology is a multivariate linear OLS regression in the timescale of 2000-2018. The paper contributes to the body of literature regarding Dutch disease studies in Azerbaijan by separately estimating the resource movement and spending effect ${ }^{2}$. Moreover, the calculated variables, such as returns on capital (ROC) and marginal propensity to consume (MPC), fill the research gap in Dutch disease-related studies in Azerbaijan. This paper improves the theoretical conceptualization of Dutch disease in the Azerbaijan economy, raising

\footnotetext{
2 The main two effects of resource dependence and a booming economy, according to the original theory.
} 
the quality of research on the subject and applying similar techniques to those that have been used in international studies of the phenomenon.

\section{Literature review and theoretical framework}

The Dutch disease hypothesis deals with the impacts of booming tradable sectors - mainly mineral products and crops - on other tradable non-resource sectors such as manufacturing and agrarian products. The Economist (1977) used the term «Dutch disease» to describe the structural changes in the development of the Netherlands economy, where the manufacturing sector declined after the discovery of natural gas resources in the Northern Sea during the 50s and 60 s of the last century. In the Netherlands, ballooned gas exports led to the appreciation of the Dutch guilder ${ }^{3}$, making the country's manufacturing and service exports expensive. The volume of non-petroleum exports relative to GDP sharply decreased, indicating a loss of competitiveness [Gylfason, 1984]. Since then, the Dutch disease model has been widely used to understand resource-rich economies because the countries with the booming sectors demonstrate similarity. Corden and Neary (1982) proposed the first model of the Dutch disease phenomenon, which explained why booming sectors negatively influence traditional manufacturing sectors.

Four broad strands of literature identify the issues related to Azerbaijan: early concerns, direct investigations of Dutch disease, indirect studies (not hypothesizing Dutch disease or its effects in their studies but including important elements related to Dutch disease) and denial of Dutch disease. The next sub-sections survey these literature stands and conclude with a research question. The last sub-section outlines the theoretical framework to conceptualize the current research.

\subsection{Early concerns of Dutch disease}

Early studies that tried to predict that Dutch disease would feature in the Azerbaijan economy dealt with the regional examinations of the Caspian basin or other resource-rich post-Soviet countries. Those studies lacked empirical analysis, heavily focused on political economy aspects, simply assumed the future outcomes of natural resource-based development would be similar to those of the other resource-rich countries of the world, and considered the Dutch disease framework to be an explanation for natural resource curse theory. For example, Mahnovski (2003) examined the oil and gas-rich Caspian basin countries. Mahnovski drew on the main characteristics of the political regimes to conclude that Dutch disease may arise after the influx of the colossal mineral revenue because Azerbaijan's authoritarian political system and weak institutions are ill-equipped to address challenges related to the volatile prices in the international markets and economic alternatives to resource growth. Kaser (2003) stressed the risks of political and economic diversification while Singh and Laurila (1999) underlined the scenario of the exchange rate overshooting in the middle and long term. De Broeck and Sløk (2001) empirically supported the argument that compared to the European Union transition countries, former Soviet countries might experience real appreciation of their national currencies during upcoming years if they

${ }^{3}$ In 2002 the Netherlands adopted the euro. The national currency of the Netherlands till the euro was the Dutch guilder. 
failed to increase their productivity level. Moreover, Singh and Laurila (1999) discussed the industrial restructuring of the adopted economic heritage because the confidence that oil revenue brings might block the development policies related to non-oil manufacturing.

\subsection{Direct investigations of Dutch disease}

Strong empirical evidence of Dutch disease has also been found. The first attempt was by Gahramanov and Fan (2002), who applied the extended Balassa - Samuelson model to analyze the consequences of the oil boom in Azerbaijan. The Balassa - Samuelson model explains how a country's national currency appreciates due to the faster efficiency growth in the tradable sector than the non-tradable sectors. Thus, the oil boom should have created a rapid REER appreciation as oil exports were rising; however, the authors concluded the absence of Dutch disease because the monetary side of their model did not show strong evidence. Nevertheless, the research period was still too early for proper evaluation of Dutch disease in the Azerbaijan economy because the oil boom was yet to come and data were scarce.

Exchange rate issues form a significant part of the Dutch disease theory. Corden (2012) has noted that the exchange rate appreciates as a response to the increase in the revenue of the booming sectors because of the high domestic prices in non-tradable sectors. This appreciation makes non-booming products more expensive to foreign buyers, reducing demand for them [Corden, 2012]. Another source of the exchange rate appreciation is the capital inflows that aim to finance the development in the booming sectors [Corden, 2012]. Hence, booming sectors should escalate inflationary processes in the economy.

Several studies covered the exchange rate and inflationary effects in the extractive industry in Azerbaijan and can be included in the category of direct investigations of the phenomenon. For example, Hasanov and Samadova (2010) used the vector error correction model to analyze the impact of REER on non-oil GDP and non-oil exports in the short-term and in the long-term period between 2002Q3-2009Q3. Their results claimed that the appreciation of REER negatively affects non-oil exports, whereas non-oil GDP boosts non-oil exports. A similar study from Hasanov (2010) based on the data ranging from 2000 to 2007 stated that that oil price is the statistically significant identifier of the value of the national currency. Therefore, $0.7 \%$ appreciation occurs if oil prices increase by $1 \%$. Hasanov highlighted the existence of Dutch disease hypotheses in the background of discussing co-integration between oil prices and real exchange rates. Huseynov (2009), Ağazade (2018), and Dikkaya and Doyar (2017) found similar results following similar methodologies (for instance the autoregressive distributed lags approach) regarding the link between the oil price shocks and the price levels in Azerbaijan.

Consequently, the devaluation or appreciation of the national currency and overestimating the oil reserves in monetary terms are useful for tracking the Dutch disease syndrome. Azerbaijan experienced two national currency devaluations in 2015 [Statement of the Central Bank of the Republic of Azerbaijan, 2015a; 2015b]. Hayat et al. (2013) provided the evidence that overestimation of oil reserves in Azerbaijan led to the REER appreciation. After the correction of the expectations regarding future income, the national currency started to depreciate. Bahmani-Oskooee and Jamilov (2014) reported that the currency depreciation shocks in Azerbaijan caused nonoil sectors to have a positive and significant response in terms of increased exports to the country's main trading partners in Europe, which indicates that there is a negative impact of oil-related exchange rate appreciation. 


\subsection{Indirect investigations of Dutch disease}

Research of the expenditure patterns of the resource-rich government might reflect the spending effect of Dutch disease. The spending effect occurs when the state uses accumulated revenue of the booming sector for various social and infrastructure projects. This increases the prices and share of GDP of the non-tradable sector, causing the national currency to appreciate in parallel with inflationary effects and sensitivity to external shocks. The main indicators of spending effect are a high share of transfers from windfall funds, high domestic prices during and after the booming period, and an increasing share of the non-tradable sector as the result of government spending. Usui (2007) pointed to the fiscal imbalance and low savings of oil money in Azerbaijan during the upsurge of commodity prices, indicating a loosened fiscal policy and instantaneous spending without institutional regulations. Furthermore, Aliyev et al. (2016) investigated fiscal policy and non-oil GDP relationships by applying OLS, autoregressive distributed lags (ARDL), and other techniques to the data based on a 2000Q1-2015Q2 time range in Azerbaijan. The findings supported Dutch disease-related studies such as from Hasanov (2013) because it estimated the positive long-run relationship between public expenditures and non-oil GDP.

Therefore, research from Sabiroglu and Bashirli (2013) tested Wagner's Law (the theory behind this law basically states that increasing the share of the public sector in the gross national product is the result of economic growth) in the case of Azerbaijan and concluded that economic growth that is heavily based on favorable oil prices that determines government expenditure. The authors did not address the spending effect of Dutch disease directly; however, the research incorporated oil price, which was a crucial factor behind the increase of public expenditure. In this case, the necessary conceptual framework for the presence of Dutch disease is obvious: high oil prices lead to high income, high income leads to high government spending, which in turn increases the number of provided services and the price. In addition, an earlier study from Koeda and Kramarenko (2008) evaluated fiscal policy scenarios via Azerbaijan-specific model simulation. The authors stated that the development of the non-oil sector and increase in total factor productivity were due to high government expenditures, although the results of the simulation indicated that it would contract after rapid cuts in government expenditure. This result is very similar to the experiences of other resource-rich countries, where government expenditures are usually high during the oil booms that follow stagnation. This trend underlines the importance of effective government expenditures during the initial stages of the booming period. Uçan and Ünal (2018) also defended the obviousness of the spending effect of Dutch disease in Azerbaijan applying the Fully Modified Ordinary Least Squares (FMOLS) method between 1996 and 2016, observing the high role of government expenditure in the economy.

\subsection{Denial of Dutch disease}

The last strand of the literature covers the studies that argue against the presence of Dutch disease effects in the economy of Azerbaijan. For instance, Sanlisoy and Ekinci (2019) applied a nonlinear autoregressive distributed lag (NARDL) analysis to 2001Q1-2018Q2 to argue that Azerbaijan did not have Dutch disease because the authors did not find any withdrawal of labor resources out of non-oil sectors. They explained their argument as follows: 
This result is based on the fact that the oil industry has become more capital-intensive sector and non-demanding for employment. The oil production increased without any slowdowns among, as well as, the other non-oil sectors. On the contrary, the increased production created additional demand in the other sectors by the help of excess revenue [Şanlisoy, Ekinci, 2019, p. 605].

However, it should be noted that the previous conclusion is based on the relationship of only two variables: real GDP and the price of crude oil (Brent trademark). This leaves out important factors such as REER, the output of lagging sectors, indicators of non-tradable sectors, and employment. However, Zulfugarov and Neuenkirch (2019) applied linear vector autoregressive models to 2002Q1-2018Q1 to argue that Azerbaijan has Dutch disease. The key results indicated decreasing quarterly GDP growth rates in both oil and non-oil sectors of the economy immediately after the oil price shocks. As oil revenue and demand for oil in the world markets decrease, the oil tradeable sector stops being profitable, which is the unconditional factor for a sharp GDP slump. Also, when oil revenue decreases, non-oil sectors lack the necessary subsidiary support from the government, which puts them in a vulnerable position; government investments also scale down.

An increased consumer price index, appreciated exchange rate, expanded construction, and slowed competition indicators point to the presence of Dutch disease rather its absence [Ibadoglu, 2008] even as the government makes various large-scale investments. However, Nuri Aras et al. (2016) and Bulut and Suleymanov (2012) argued that SOFAZ spendings were the measures against Dutch disease because such activities fill the financial gap in non-oil sectors and increase the welfare of groups such as internally displaced people from the Nagorno Karabakh war, who were challenged by unemployment and a loss of the permanent place of residence. Nevertheless, the authors described such activities as insufficient; without «projects inclined to the advance of industrial areas having export potential» [Nuri Aras et al., 2016, p. 232], overcoming the challenges of Dutch disease effects might fail ${ }^{4}$. Ibadoglu (2008, p. 425) mentioned an important aspect of those expenditures: "The so-called "light oil money" made state officials feel careless and diverted them from thinking about balanced and sustainable development to the fight for quick sharing of oil revenues as though they were in competition». Ultimately, massive government spending towards infrastructure projects and social programs boosted the spending effect [Hasanov, 2013].

Egert (2012) has argued that due to data issues, it is impossible to track resource movement and spending effects among the post-Soviet countries - including Azerbaijan - but concluded that increased oil prices resulted in appreciated nominal currency after certain time lags. Yun (2018) analyzed the connection between REER and manufacturing employment and between oil price and manufacturing output between 1991 and 2017 to conclude that there was significant de-industrialization and oil dependence in the Azerbaijan economy. Niftiyev (2020) also described de-industrialization signs in the case of Azerbaijan resulting from Dutch disease which is a notable result of the exchange rate appreciation.

Thus, the body of literature provides contradictory evidence of Dutch disease in the economy of Azerbaijan. This study attempts to shed light on the effects of that phenomenon through the following research question: does the economy of Azerbaijan demonstrate the signs of Dutch disease in line with the theoretical expectations of the core model?

\footnotetext{
4 The authors also argue that the independence of SOFAZ and the role of free economic zones are accommodative responses to the economic diversification issues.
} 


\subsection{Theoretical framework - how does the Dutch disease model work?}

Corden and Neary (1982) modeled Dutch disease effects based on an open small economy. The theory assumes three sectors: booming sectors (hereafter $\mathrm{SB}$ ), lagging sectors (hereafter $\mathrm{S}_{\mathrm{L}}$ ), and non-tradable sectors (hereafter $\mathrm{S}_{\mathrm{NT}}$ ). In Azerbaijan, $\mathrm{S}_{\mathrm{B}}$ consists of oil and gas sectors, while $\mathrm{S}_{\mathrm{L}}$ mainly comprises non-oil manufacturing and agriculture. Both $\mathrm{S}_{\mathrm{B}}$ and $\mathrm{S}_{\mathrm{L}}$ are tradable sectors, and the world markets determine the prices of these sectors. $S_{\mathrm{NT}}$ are tertiary sectors, and the prices of non-tradable goods are determined domestically. Mironov and Petronevich (2015) summarized other core assumptions of the model as follows. The economy consists of two production factors: labor and capital; labor-to-capital ratio varies across the sectors; labor is mobile, although capital is specific (at least in the short-run); there is full employment; the labor market is flexible; and household consumption is the only source of the internal demand.

Dutch disease occurs through the two effects: the resource movement effect and spending effect. Graph 1 demonstrates the general mechanism of the resource movement effect, which is the withdrawal of the labour and capital towards $S_{B}$ out of $S_{L}$ and $S_{N T}$.

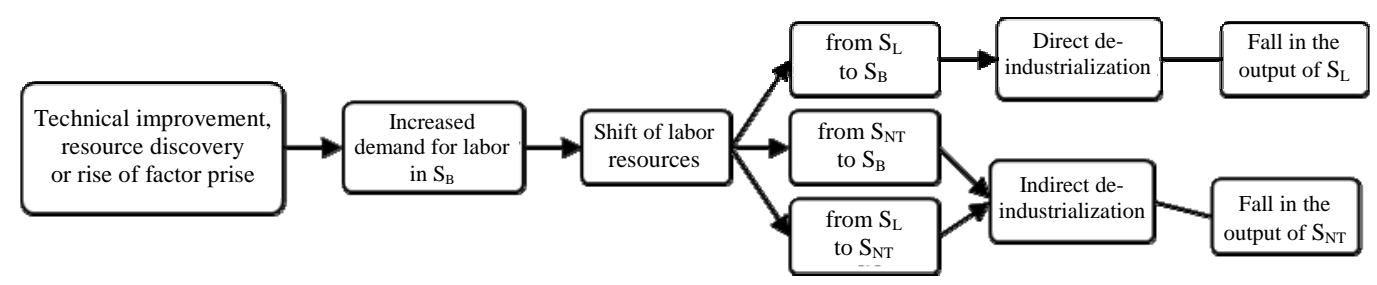

Graph 1. Resource movement effect

Source: Own construction based on Corden (1984).

This is the result of the rise in the demand for the labour in $\mathrm{S}_{\mathrm{B}}$. Resource movement might happen in two ways:

1) The output of $S_{L}$ decreases because the labor moves into $S_{B}$ (direct de-industrialization, without real exchange rate appreciation).

2) The movement of labour from $S_{\mathrm{NT}}$ into $S_{\mathrm{B}}$ moves in parallel with the shift of the labour from $S_{\mathrm{L}}$ to $\mathrm{S}_{\mathrm{NT}}$, creating an excess demand in $\mathrm{S}_{\mathrm{NT}}$ (indirect de-industrialization, with real exchange rate appreciation).

The resource movement effect is rare in the low-income countries where mineral sectors employ inputs that are imported from abroad [Brahmbhatt et al., 2010]. Corden and Neary (1982) have mentioned the negligible nature of resource movement when booming sectors use few resources. If so, the boom is a form of the spending of the accumulated revenue, which is the spending effect of the model (see Graph 2).

The spending effect occurs when a part of extra income is spent either by the factory owners directly (i.e., when a firm spends on intermediate inputs) or indirectly via government expenditure (where the government is the recipient of the revenue in a form of royalties, taxes, or profits) [Corden, 1984]. Corden (2012) emphasized that the spending effect is concerned only with the spending «at home», which is different from the spending on imports, the transfers of premiums overseas, and the acquisition of foreign assets. Moreover, a special case results when $S_{B}$ 
does not participate in the domestic factor markets and does not employ a mobile factor in the economy during the oil boom. In this case, $\mathrm{S}_{\mathrm{B}}$ is an «enclave» ${ }^{5}$ [Corden, 1984], the economy does not experience direct de-industrialization (resource movement effect is absent), and resource allocation happens throughout the real appreciation. Thus, the spending effect leads to the movement of the resources from $S_{B}$ and $S_{\mathrm{L}}$ into $S_{\mathrm{NT}}$, while demand occurs in the opposite direction from $S_{\mathrm{NT}}$ to $S_{\mathrm{B}}$ and $\mathrm{S}_{\mathrm{L}}$. The main outcomes of the spending effect are higher output in $\mathrm{S}_{\mathrm{NT}}$ during and after the boom compared to the pre-boom period.

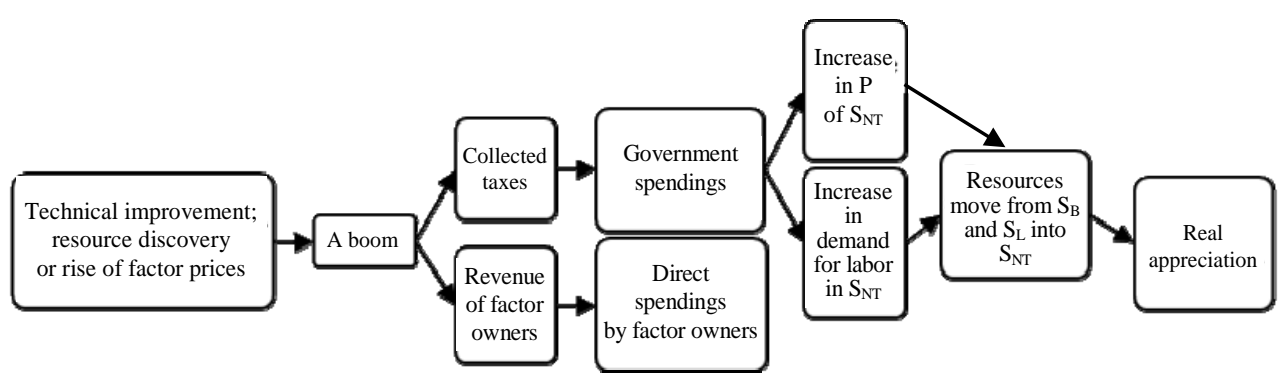

Graph 2. Spending effect

Source: Own construction based on Corden (1984).

Corden (1984) listed other core assumptions related to income distribution: the resource movement effect and spending effect lower the rents of the specific factor in $\mathrm{S}_{\mathrm{L}}$, rents in $\mathrm{S}_{\mathrm{B}}$ unambiguously rise because the marginal product of labor rises or favorable exogenous factors make this sector more profitable, and rents in SNT may rise or may not rise according to the changes in the output and real wages of other sectors. These clarifications help to understand the initial signals that direct the labor and capital resources on how to act in the face of the constantly changing oil prices in the world markets and profitability levels in the national economy.

Then, both effects increase the wages level in the economy in terms of $S_{L}$ because a rise in labor demand in $S_{\mathrm{B}}$ and $S_{\mathrm{NT}}$. However, in the case of the spending effect due to the rise of the price of $\mathrm{S}_{\mathrm{NT}}$, real wages sometimes may fall or rise. Since wage-earners also consume goods and services from $\mathrm{S}_{\mathrm{NT}}$, the real wage dynamics are obscure (real wages also may fall, especially in the case of the spending effect). However, when the resource movement effect occurs, real wages must rise because the fallen output of $S_{\mathrm{NT}}$ increases the wages in $\mathrm{S}_{\mathrm{B}}$ in terms of $\mathrm{S}_{\mathrm{NT}}$.

The next section provides an overview of the main macroeconomic indicators of Azerbaijan's economy.

\section{Increased role of oil and Dutch disease signs in the Azerbaijan economy: macroeconomic survey}

Without noteworthy changes in the reserves, oil and natural gas production surged between 2007-2008 with moderate declines in oil production since 2011 (see Fig. 1a). Figure 1,

${ }^{5}$ An enclave is rather a metaphorical term to describe the situation when a single sector carries the rest of the economy similar to a train that usually has only one locomotive. 
panel $b$ indicates the period of the export booming of crude oil that peaked in 2009 and 2010. Meanwhile, natural gas exports gradually increased, starting from 2009. Establishing natural gas agreements with the interested parties took longer than for oil agreements. The most visible sign of the increased role of oil and gas sector in Azerbaijan was the increased share of SOFAZ in the state budget (see Fig. 1b).

Panel a of Fig. 2 illustrates FDI inflows into oil and non-oil sectors. Between 2000-2008 (until the edge of the boom years for output and revenue), there was a significant difference between FDI inflows. All these boosted the cumulative growth rates (CGRs) of oil GDP while non-oil GDP between 2000-2017 (see Fig. 2b) was lower. The difference between CGR in oil GDP and non-oil GDP slightly narrowed in 2015 but started to grow again after 2016.

Mineral revenue increased overall government spending as a percentage of GDP between 2000 and 2014 by approximately 19\%. SOFAZ's increased transfers to the state budget and possession of more than 50\% share in oil GDP (see Fig. 2, panel b) indicate how oil wealth started to dominate the economy.

The abovementioned trends in the oil and gas industry, accompanied by the period of high oil prices, created benign conditions for rapid economic growth. The GDP of Azerbaijan exhibited recovering signs after the painful transition process but also achieved very high growth rates (28\%, 35.5\%, and 25.5\% respectively in 2005, 2006 and 2007 - see Fig. 3a). Naturally, the share of the mining sector in real value-added GDP peaked in 2007 by $56.3 \%$ then gradually slowed down and halved in 2016, as demonstrated by panel b of Fig. 3. However, manufacturing valueadded in real GDP never exceeded the share of $7 \%$ after 2005 ; it hovered around $4.7 \%$ on average per year during and after the oil booming period, whilst the agriculture sector experienced moderate slowdowns (from $9.3 \%$ in 2005 to 5.8\% in 2017). As Hasanov (2013) has argued, due to social development and infrastructure-based government spending, the tertiary sector expanded its share in real value-added GDP since the oil boom: 50\% in 2016 and 2017. Nevertheless, despite the increased role of the extractive industry, GDP growth plummeted due to the sharp commodity price downturns during 2014-2015 (see Fig. 3a).

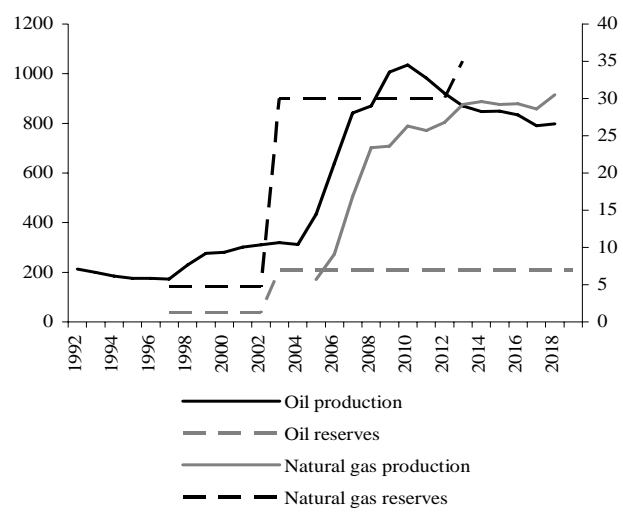

a. Oil production (thousand barrels per day), oil reserves (billion barrels, right axis), natural gas production (billion $\mathrm{m}^{3}$, right axis) and natural gas reserves (trillion cubic feet)

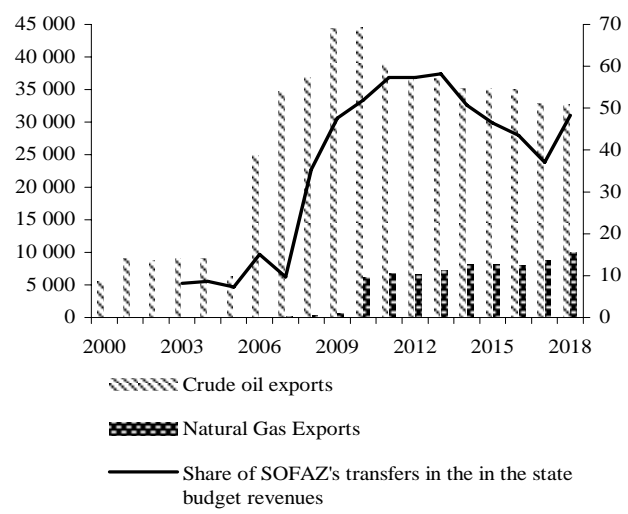

b. Oil (in thousand tons) and gas (in thousand tons) exports and increasing role of oil revenue in the state budget (as \% share in the state budget, right axis, measured by million AZN)

Fig. 1. The share of the oil and gas sector in the economy of Azerbaijan

Source: State Statistical Committee of The Republic of Azerbaijan (SSCRA), Reports of SOFAZ (2020). 
The oil boom was positive for a collapsed economy such as Azerbaijan's. Growth in mineral revenue increased the well-being and social welfare of the citizens more than other neighboring post-Soviet countries. Measured by constant 2011 PPP USD, GDP per employed person employed averaged around 34,014 USD per year between 2009 and 2019; that same metric was 15,179 USD per year between 1991-2009 [World Bank, 2020f]. During and after the booming period (20082011), GDP per capita measured by constant 2011 international USD also grew: in 2010 it was 16,215.8 USD, 16,828.9 USD in 2015, and 16,010.9 USD in 2018. In neighboring countries like Armenia and Georgia, the mentioned indicator was approximately two times lesser.

However, there was arguably excessive dependency on oil production. These dependencies mirror the bitter realities during the sharp commodity price downturns (i.e., negative economic growth, decreased GDP). Furthermore, an overvalued national currency and a lack of incentives to diversify the economy harm the competitiveness of the non-oil sectors. Falkowski's (2018) study of revealed comparative advantages stressed that Azerbaijan's overall competitiveness was very low between 2000-2015. Non-oil sectors underperformed due to the low level of productivity and passive non-oil developments compared to the development of mining, construction, and trade [Huseynov, 2017]. That is why this study seeks to use the Dutch disease model to shed light on the extractive industry's effect on other sectors.

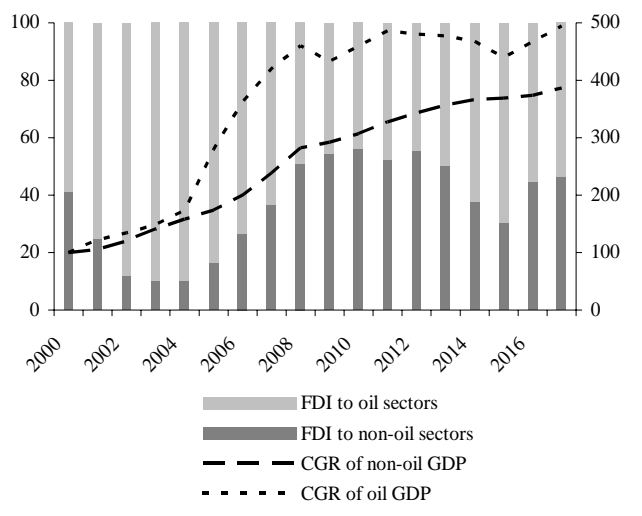

a. FDI to oil and non-oil sectors of the economy (in \%, relative to the gross total, measured by million USD) and cumulative growth rate (CGR) of oil and nonoil GDP (in \%, right axis, measured by million AZN, current prices)

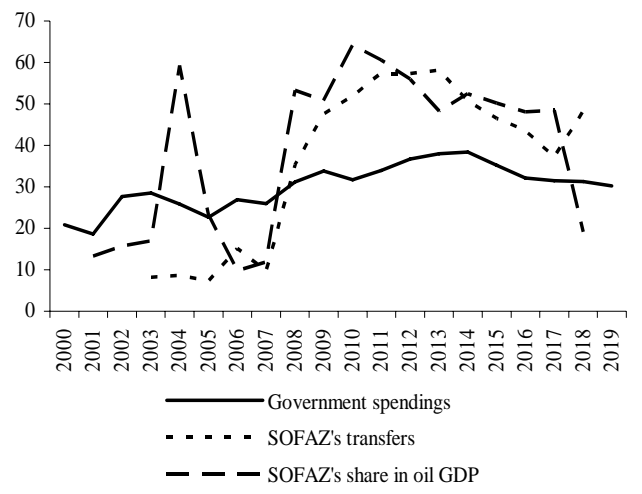

b. Overall government spending (\% of GDP), the share of SOFAZ in the state budget (in \%), and the share of the revenue of SOFAZ in the oil GDP (in \%)

Fig. 2. Sectoral distribution of FDI, GDP, and government expenditure 


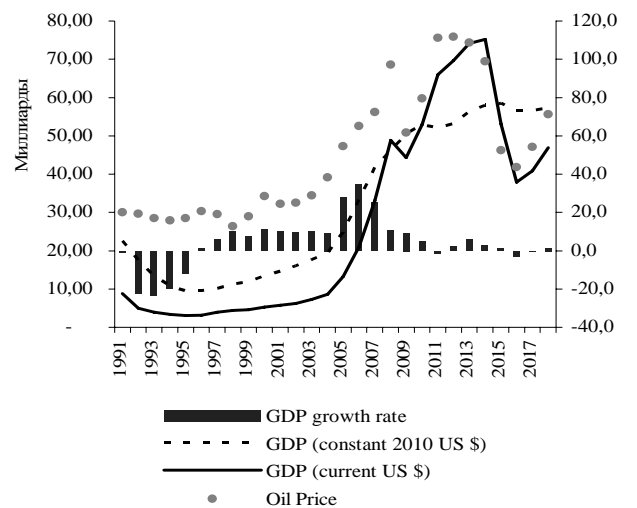

a. Current (in USD) and Constant GDP (Constant 2010 USD), Brent oil price (right axis) - in USD per barrel, GDP growth rate (right axis) - annual \%

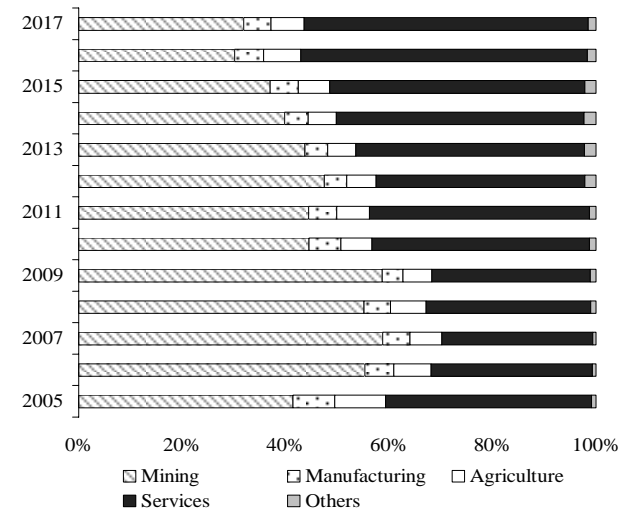

b. Decomposition of real GDP value-added, chain-linking method, in \%

Fig. 3. The connection of the economic growth, oil prices and structural change

Source: SSCRA, World Bank national accounts data, OECD National Accounts data files, BP -Statistical Review of World Energy (2019) and author's calculation.

\section{Data and methods}

This study uses multivariate linear OLS regression equations that adopt an aggregated three-sector approach to test the resource movement and spending effects of the Dutch disease model. This approach was used by Corden and Neary (1982) and Corden (1984) to theorize the Dutch disease concept.

OLS regression enters into the group of the most popular statistical methods in the social sciences [Hutcheson, Sofroniou, 1999]. The overall design of the equations is similar to those used by Mironov and Petronovich (2015) in the case of Russia because of the appropriateness and optimal adaptations of the employed models in terms of collected data in Azerbaijan's case which is similar to Russia. More specifically, output, employment, real wages, and returns on capital growth rates among booming, lagging, and non-tradable sectors were analyzed following the different specifications of the main equation 1 . Then equations 2 and 3 are the model specifications for the resource movement and spending effects respectively (various independent variables have been excluded and included to check the results of different versions of the core equation) ${ }^{6}$.

$$
\begin{aligned}
& \text { Output GR } / \text { Employment } G R_{t} / \text { Real Wages GR } / \text { Returns on Capital } G R_{t}= \\
& =\beta_{0}+\beta_{1} \text { Oilp }_{t} \text { GR }+\beta_{2} \text { Economic Crises }_{t}+\beta_{3}\left(\text { REER }_{t} ; N E E R_{t}\right)+\varepsilon_{t} \text {, } \\
& \text { Output } G R_{t} / \text { Employment } G R_{t}=\beta_{0}+\beta_{1} S_{B} G R_{t}+\beta_{2} S_{L} G R_{t}+\beta_{3} S_{N T} G R_{t}+ \\
& \left.+\beta_{4} \text { (Popuation income in } U S D_{t} \text {; Popuation income in } A Z N_{t}\right)+\varepsilon_{t} \text {, }
\end{aligned}
$$$$
\text { (2) }
$$

6 The abbreviation of «GR» means growth rate among the listed formulas; "/" does not indicate the division sign, it shows multiple dependent variables at the same formula; $\varepsilon$ is the error term; «t» denotes the time. 
CPI GR $/$ REER GR $/$ NEER GR
$+\beta_{3}$ Popuation income in $U S D_{t}+$

$+\beta_{4}\left(\right.$ Government spendings in bil. USD $D_{t}$; Government spendings as a share of $\left.G D P_{t}\right)+\varepsilon_{t}$.

Table 1 explains the variables of interest. See Table 2 for an in-depth exploration and measurement levels of data.

\section{Explanation of the variables of interest in the estimations}

Table 1.

\begin{tabular}{|c|c|}
\hline Variable & Explanation \\
\hline Output GR - Estimation 1, 2 & $\begin{array}{l}\text { Output growth rate in booming, lagging, or non- } \\
\text { tradable sectors in year-over-year percentage } \\
\text { (depending on the model) }\end{array}$ \\
\hline Employment GR - Estimation 1, 2 & $\begin{array}{l}\text { Employment growth rate in booming, lagging, } \\
\text { or non-tradable sectors in year-over-year per- } \\
\text { centage (depending on the model) }\end{array}$ \\
\hline Real Wages GR - Estimation 1 & $\begin{array}{l}\text { Real wages growth rate in booming, lagging, } \\
\text { or non-tradable sectors in year-over-year per- } \\
\text { centage (depending on the model) }\end{array}$ \\
\hline Return on Capital GR - Estimation 1 & $\begin{array}{l}\text { Return on capital growth rate in booming, lagging, or } \\
\text { non-tradable sectors in year-over-year percentage }\end{array}$ \\
\hline CPI GR - Estimation 3 & Year-over-year growth rates in Consumer Price Index \\
\hline Oil p. GR - Estimation 1 & Year-over-year growth rates in annual oil prices \\
\hline Economic Crises - Estimation 1 & Dummy variable (2008-2009; 2014-2015) \\
\hline REER - Estimation 1 & Real Effective Exchange Rate \\
\hline REER GR -Estimation 3 & $\begin{array}{l}\text { Year-over-year growth rate of Real Effective Ex- } \\
\text { change Rate }\end{array}$ \\
\hline NEER - Estimation 1 & Nominal Effective Exchange Rate \\
\hline NEER GR - Estimation 3 & $\begin{array}{l}\text { Year-over-year growth rate of Nominal Effective } \\
\text { Exchange Rate }\end{array}$ \\
\hline $\mathrm{S}_{\mathrm{B}} \mathrm{GR}$ - Estimation 2 & $\begin{array}{l}\text { Year-over-year growth rates of output, employ- } \\
\text { ment, or real wages in booming sectors }\end{array}$ \\
\hline $\mathrm{S}_{\mathrm{L}} \mathrm{GR}$ - Estimation 2 & $\begin{array}{l}\text { Year-over-year growth rates of output, employ- } \\
\text { ment, or real wages in lagging sectors }\end{array}$ \\
\hline $\mathrm{S}_{\mathrm{NT}} \mathrm{GR}-$ Estimation 2 & $\begin{array}{l}\text { Year-over-year growth rates of output, employ- } \\
\text { ment, or real wages in non-tradable sectors }\end{array}$ \\
\hline Population income in USD - Estimation 2, 3 & Population income variable \\
\hline Population income in AZN - Estimation 2 & Population income variable \\
\hline MPC - Estimation 3 & Marginal Propensity to Consume \\
\hline $\mathrm{S}_{\mathrm{NT}}$ output - Estimation 3 & The output of non-tradable sectors \\
\hline Government spendings in bil. USD - Estimation 3 & Government spendings \\
\hline $\begin{array}{l}\text { Government spendings as a share of GDP - } \\
\text { Estimation } 3\end{array}$ & Government spendings \\
\hline
\end{tabular}


In this research, booming sectors include mining, oil and gas extraction, and petroleum and fuel production data. Lagging sectors include agriculture, fishing, forestry, and non-oil manufacturing. Non-tradable sectors include construction, trade, transportation, and storage; accommodation and food service activities; information and communication; financial and insurance activities; real estate activities; professional, scientific, and technical activities; administrative and support service activities; public administration and defense; social security, education, human health and social work activities; art, entertainment, and recreation, and other service activities ${ }^{7}$. The coverage period is between $2000-2018$ for all variables, excluding returns on capital. The following paragraphs describe all variables used in the estimations and provide the descriptive statistics.

\subsection{In-depth explanation and description of the variables}

Employment data captures the number of the employed population (out of a thousand) in sectors in the economy. The data source is the State Statistical Committee of the Republic of Azerbaijan [SSCRA, 2020a].

The booming sector's output is the total of the value of the output of the mining sector and the production of petroleum products provided by SSCRA (2020b) in current AZN. Similarly, lagging sectors' output is comprised of the total output value of manufacturing (non-oil production) and agriculture in current AZN [SSCRA, 2020b; 2020c]. Meanwhile, the data related to the services have been calculated by the World Bank based on the value-added in services (or nontradable sectors) (2020g). The original data regarded services were in current USD and were converted to the current AZN by the exchange rate of 1.70AZN/USD, which follows the official exchange rate of AZN/USD according to Central Bank of the Republic of Azerbaijan (CBAR). The missing value of 2018 was replaced by the average between 2007-2017.

The data obtained from SSCRA (2020d) pertains to the average monthly nominal wages and salaries (in AZN) among the economic sectors (following the same sectoral classification denoted in employment and output). Those data were used to calculate the real wages. Nominal wages were adjusted by Azerbaijan's CPI as provided by the World Bank (2020i), taking the year of 2010 as $100 \%$.

An average of 12 months' annual data on oil prices (Brent trademark) between 2000-2018 were pulled from Indexmundi (2020). NEER and REER data were pulled from the official data set provided by the CBAR (2020).

The income of the population in terms of current AZN and current USD was drawn from SSCRA's official statistical yearbook that is dedicated to national accounts [SSCRA, 2019]. There is a dummy variable that covers 2008-2009 and 2014-2015 years as economic crisis periods.

Returns on capital (ROC) for booming, lagging and non-tradable sectors were calculated with the help of SSCRA's income account in current prices in terms of million AZN [SSCRA, 2020e]. However, a few caveats are necessary. As a form of ready data, the sectoral distribution of the ROC is not provided by official data sources such as SSCRA. Thus, that data was calculated between 2005 and 2017. The variable is the ratio of the net operable surplus over the directed investments (both foreign and domestic investments to industry, provided by SSCRA (2020f)). The

7 For instance, when aggregated variables were calculated for the non-tradable sector, the total of listed indicators were averaged to the used variable count. 
source for the directed investments to agriculture and non-tradable sectors is SSCRA (2020g). The booming sector's ROC does not include the petroleum production sector's data. All other calculations are the same as the above-mentioned compositions of the three-sector approach.

There are other variables that were mainly tested within the spending effect of the Dutch disease hypothesis. These variables are population income (in current AZN and current USD, [SSCRA, 2019]; government spending in billions of USD [The Global Economy, World Bank, 2020a] and as a percentage share of GDP [The Global Economy, World Bank, 2020b]; marginal propensity to consume (calculated based on the following data - [SSCRA, 2019], and consumer price index [SSCRA, 2020i]. Missing values for MPC (2000 and 2018) were replaced by the series mean.

Table 2 depicts the summary statistics, normality test (Shapiro - Wilk), and Pearson's correlation (against oil prices) of the variables. How the data is distributed is a crucial starting point for the analysis. Thus, a $p$-value of less than 0.05 indicates an non-normally distributed, and a $p$-value that is greater than 0.05 demonstrates a normally distributed data. Lastly, while a Pearson's $r$ coefficient that is close to 1 indicates a strong positive correlation, coefficients that are close to -1 demonstrate a strong negative correlation.

Table 2.

Descriptive statistics, normality test, and correlation coefficients (against oil prices) of the selected variables of interest, 2000-2018

\begin{tabular}{|c|c|c|c|c|c|c|}
\hline Variables & Min & Max & Mean & S.D. & $\begin{array}{l}\text { Shapiro- } \\
\text { Wilk Test }\end{array}$ & $\begin{array}{l}\text { Pearson's } \\
\text { correlation }\end{array}$ \\
\hline$S_{B}$ employed, thsd. persons & 37.90 & 44.30 & 41.30 & 2.00 & 0.942 & 0.421 \\
\hline SL employed, thsd. persons & $1,696.7$ & $2,024.1$ & $1,842.7$ & 99.40 & 0.963 & $0.485^{*}$ \\
\hline $\mathrm{S}_{\mathrm{NT}}$ employed, thsd. persons & 2068.4 & $2,746.3$ & $2,371.1$ & 226.20 & 0.926 & 0.426 \\
\hline$S_{B}$ output, current mil. AZN & $2,186.7$ & 37761.7 & $17,765.5$ & $11,416.3$ & 0.906 & $0.757^{* *}$ \\
\hline $\mathrm{S}_{\mathrm{L}}$ output, current mil. AZN & 2102.2 & $14,645.2$ & $7,303.9$ & $3,974.0$ & 0.942 & $0.495^{*}$ \\
\hline S $_{\mathrm{NT}}$ output, current mil. AZN & $1,092.0$ & 14871.8 & $6,760.8$ & $4,746.4$ & $0.900^{*}$ & $0.743^{* *}$ \\
\hline $\mathrm{S}_{\mathrm{B}}$ real wages, AZN & 333.25 & $2,120.44$ & $1,164.3$ & 534.3 & 0.944 & 0.346 \\
\hline $\mathrm{S}_{\mathrm{L}}$ real wages, AZN & 72.11 & 328.59 & 204.50 & 88.70 & 0.918 & $0.656^{* *}$ \\
\hline $\mathrm{S}_{\mathrm{NT}}$ real wages, AZN & 111.67 & 447.98 & 335.40 & 112.00 & $0.850^{*}$ & $0.735^{* *}$ \\
\hline$S_{B}$ returns on capital, ratio & 1.19 & 7.23 & 4.14 & 2.15 & 0.911 & $0.649^{*}$ \\
\hline$S_{\mathrm{L}}$ returns on capital, ratio & 1.84 & 11.90 & 5.05 & 3.01 & $0.837^{*}$ & $-0.581^{*}$ \\
\hline $\mathrm{S}_{\mathrm{NT}}$ returns on capital, ratio & 1.06 & 3.28 & 1.81 & 0.72 & $0.772^{*}$ & $-0.556^{*}$ \\
\hline $\begin{array}{l}\text { Real Effective Exchange } \\
\text { Rate (REER), } 2000=100 \%\end{array}$ & 74.20 & 134.60 & 104.60 & 19.76 & 0.907 & $0.777^{* *}$ \\
\hline $\begin{array}{l}\text { Nominal Effective Exchange } \\
\text { Rate (NEER), } 2000=100 \%\end{array}$ & 65.46 & 113.28 & 93.33 & 14.08 & 0.909 & 0.363 \\
\hline $\begin{array}{l}\text { Oil price, Brent trademark, } \\
\text { in USD }\end{array}$ & 24.42 & 111.97 & 64.69 & 30.01 & 0.925 & - \\
\hline
\end{tabular}


Continues

\begin{tabular}{l|c|c|c|c|c|c}
\hline \multicolumn{1}{c|}{ Variables } & Min & Max & Mean & S.D. & $\begin{array}{c}\text { Shapiro- } \\
\text { Wilk Test }\end{array}$ & $\begin{array}{c}\text { Pearson's } \\
\text { correlation }\end{array}$ \\
\hline $\begin{array}{l}\text { Income of population, } \\
\text { current USD }\end{array}$ & $4,523.10$ & $50,321.50$ & $24,180.51$ & $15,865.62$ & 0.906 & $0.803^{* *}$ \\
$\begin{array}{l}\text { Government spending, } \\
\text { billion USD }\end{array}$ & 0.77 & 8.19 & 4.01 & 2.61 & $0.900^{*}$ & $0.810^{* *}$ \\
$\begin{array}{l}\text { Government spending, \% } \\
\text { share of GDP }\end{array}$ & 8.50 & 15.15 & 11.27 & 1.71 & 0.965 & $-0.723^{* *}$ \\
$\begin{array}{l}\text { Marginal propensity to } \\
\text { consume (MPC), ratio }\end{array}$ & 0.49 & 1.77 & 0.85 & 0.35 & $0.866^{*}$ & -0.161 \\
$\begin{array}{l}\text { Consumer price index } \\
\text { (CPI), in \% }\end{array}$ & 98.80 & 125.30 & 104.62 & 6.25 & $0.780^{*}$ & 0.242 \\
\hline \hline
\end{tabular}

Note: $1{ }^{*}$ - indicates that the $p$-value is smaller than 0.05 or in other words, non-normal distribution under the «Shapiro - Wilk Test» column; 2) ** - correlation is significant at the 0.01 level (2-tailed); 3 ) * correlation is significant at the 0.05 level (2-tailed) under the «Pearson's Correlation» column; and 4) S.D. denotes standard deviation.

The results from the Shapiro - Wilk test indicated that some of the variables are not normally distributed. Furthermore, Strong, significant, and positive correlation coefficients against oil prices belong to output in $S_{\mathrm{B}}$ and in $\mathrm{S}_{\mathrm{NT}}$, while real wages in $\mathrm{S}_{\mathrm{L}}$ and $\mathrm{S}_{\mathrm{NT}}$, REER, and income of the population, both in USD and AZN. Interestingly, government spending as a percentage share of GDP indicated a strong, significant, and negative correlation with oil prices. Other negative and significant correlations include returns on capital in $\mathrm{S}_{\mathrm{L}}$ and $\mathrm{S}_{\mathrm{NT}}$.

\subsection{Stationarity}

Collected time series data in its raw form were highly non-stationary, excluding minor examples such as CPI. The data were transformed to year-on-year (y-o-y) percentage changes because this study investigates the impact of various explanatory variables based on the core Dutch disease model on output, employment, real wage, and capital accumulation. However, application of augmented Dickey - Fuller (ADF) [Dickey, Fuller, 1981] and Philips Perron (PP) [Philips, Perron, 1988] tests with intercept, intercept and trend, and without intercept and trend revealed that nearly half of the variables were still non-stationary. That is why year-on-year percentage changes were also transformed into the first difference. After the last transformation, all variables were highly stationary ${ }^{8}$.

8 The results of stationarity tests have not been reported here to save space; however, they can be found in Table A1 and A2 in the Appendix section of this paper. 


\section{Results}

Table 3 provides the results of the impact of oil prices, REER, NEER, and economic crisis on the booming, lagging, and non-tradable sectors. This sheds light on the general theoretical expectations that Dutch disease effects might create for non-booming sectors in the economy.

Output growth rates were positively associated with the oil prices growth rate, and in model 3 even the output of the lagging sectors was in a positive relationship. Only one model produced a negative relationship between oil price changes and employment in $\mathrm{S}_{\mathrm{NT}}$. Moreover, changes in the oil prices had positive and significant impacts and returns on the capital growth rate in $S_{B}$, while returns on capital in $S_{L}$ and $S_{N T}$ were negatively associated with changes to oil prices.

Surprising findings were that REER and NEER had less significant impacts on the economic sectors. Only Model 12 produced a statistically significant and positive outcome between NEER and employment in $\mathrm{S}_{\mathrm{NT}}$.

The constructed models are trustworthy despite having low values of R-squared. All models passed the heteroscedasticity test and excluding models 17 and 18, other models showed normally distributed residuals (lower rows in Table 3). Models number 9, 10, 13, 14, 21, and 22 displayed serial correlation issues, so this aspect should be considered when using the results of the mentioned models.

Table 3.

Sectoral distribution of the impact of oil prices, REER, NEER, and economic crisis, OLS results, 2000-2018

\begin{tabular}{|c|c|c|c|c|c|c|c|c|c|c|c|c|}
\hline \multirow{4}{*}{ Exp.var } & \multicolumn{12}{|c|}{ Dependent variable } \\
\hline & \multicolumn{6}{|c|}{ Output growth rate: } & \multicolumn{6}{|c|}{ Employment growth rate: } \\
\hline & \multicolumn{2}{|c|}{$\mathrm{S}_{\mathrm{B}}$} & \multicolumn{2}{|c|}{$\mathrm{S}_{\mathrm{L}}$} & \multicolumn{2}{|c|}{$\mathrm{S}_{\mathrm{NT}}$} & \multicolumn{2}{|c|}{$\mathrm{S}_{\mathrm{B}}$} & \multicolumn{2}{|c|}{$\mathrm{S}_{\mathrm{L}}$} & \multicolumn{2}{|c|}{$\mathrm{S}_{\mathrm{NT}}$} \\
\hline & $(1)$ & $(2)$ & (3) & (4) & (5) & (6) & (7) & $(8)$ & (9) & $(10)$ & (11) & $(12)$ \\
\hline Intercept & $\begin{array}{l}10.59 \\
{[0.37]}\end{array}$ & $\begin{array}{l}-21.79 \\
{[-0.61]}\end{array}$ & $\begin{array}{r}0.84 \\
{[-0.21]}\end{array}$ & $\begin{array}{l}-7.95 \\
{[0.49]}\end{array}$ & $\begin{array}{l}16.28 \\
{[0.88]}\end{array}$ & $\begin{array}{l}20.42 \\
{[0.88]}\end{array}$ & $\begin{array}{r}2.40 \\
{[0.52]}\end{array}$ & $\begin{array}{r}4.04 \\
{[0.70]}\end{array}$ & $\begin{array}{r}0.54 \\
{[0.60]}\end{array}$ & $\begin{array}{r}0.58 \\
{[0.52]}\end{array}$ & $\begin{array}{r}-0.49 \\
{[-1.13]}\end{array}$ & $\begin{array}{l}-1.27^{* *} \\
{[-2.72]}\end{array}$ \\
\hline Oil p.-GR & $\begin{array}{l}0.63^{* * *} \\
{[3.62]}\end{array}$ & $\begin{array}{l}0.65^{* * *} \\
{[3.73]}\end{array}$ & $\begin{array}{r}0.11^{*} \\
{[2.00]}\end{array}$ & $\begin{array}{r}0.12 \\
{[2.11]}\end{array}$ & $\begin{array}{r}0.19 \\
{[1.67]}\end{array}$ & $\begin{array}{r}0.18 \\
{[1.55]}\end{array}$ & $\begin{array}{r}0.01 \\
{[0.32]}\end{array}$ & $\begin{array}{r}0.01 \\
{[0.26]}\end{array}$ & $\begin{array}{r}-0.01 \\
{[-0.06]}\end{array}$ & $\begin{array}{r}-0.01 \\
{[-0.12]}\end{array}$ & $\begin{array}{r}-0.01 \\
{[-2.44]}\end{array}$ & $\begin{array}{l}-0.01 * * \\
{[-2.40]}\end{array}$ \\
\hline $\begin{array}{l}\text { Economic } \\
\text { crisis }\end{array}$ & $\begin{array}{r}-9.97 \\
{[-0.68]}\end{array}$ & $\begin{array}{l}-15.57 \\
{[-1.13]}\end{array}$ & $\begin{array}{r}-4.53 \\
{[-0.97]}\end{array}$ & $\begin{array}{l}-5.20 \\
{[0.26]}\end{array}$ & $\begin{array}{r}-7.99 \\
{[-0.85]}\end{array}$ & $\begin{array}{r}-8.69 \\
{[-0.97]}\end{array}$ & $\begin{array}{r}-3.99 \\
{[-1.69]}\end{array}$ & $\begin{array}{r}-3.82 \\
{[-1.70]}\end{array}$ & $\begin{array}{r}0.08 \\
{[0.17]}\end{array}$ & $\begin{array}{r}0.03 \\
{[0.08]}\end{array}$ & $\begin{array}{r}-0.08 \\
{[-0.38]}\end{array}$ & $\begin{array}{r}-0.15 \\
{[-0.85]}\end{array}$ \\
\hline REER & $\begin{array}{r}-0.08 \\
{[-0.30]}\end{array}$ & & $\begin{array}{r}0.02 \\
{[0.80]}\end{array}$ & & $\begin{array}{l}-0.14 \\
{[0.46]}\end{array}$ & & $\begin{array}{l}-0.01 \\
{[0.52]}\end{array}$ & & $\begin{array}{r}-0.01 \\
{[-0.58]}\end{array}$ & & $\begin{array}{r}0.01 \\
{[1.13]}\end{array}$ & \\
\hline NEER & & $\begin{array}{r}0.27 \\
{[0.50]} \\
\end{array}$ & & $\begin{array}{r}0.09 \\
{[0.75]} \\
\end{array}$ & & $\begin{array}{r}-0.20 \\
{[0.88]}\end{array}$ & & $\begin{array}{r}-0.03 \\
{[0.70]}\end{array}$ & & $\begin{array}{r}-0.01 \\
{[-0.49]} \\
\end{array}$ & & $\begin{array}{l}0.011^{* *} \\
{[2.74]}\end{array}$ \\
\hline R sq. & 0.56 & 0.57 & 0.33 & 0.35 & 0.35 & 0.25 & 0.26 & 0.26 & 0.02 & 0.01 & 0.36 & 0.52 \\
\hline Adj. R sq. & 0.46 & 0.47 & 0.18 & 0.20 & 0.20 & 0.20 & 0.09 & 0.09 & -0.21 & -0.21 & 0.21 & 0.41 \\
\hline F-stat. & 5.50 & 5.72 & 2.14 & 2.33 & 2.33 & 2.34 & 1.51 & 1.56 & 0.09 & 0.07 & 2.40 & 4.69 \\
\hline Prob (F-stat) & 0.01 & 0.01 & 0.14 & 0.12 & 0.12 & 0.12 & 0.26 & 0.25 & 0.96 & 0.98 & 0.12 & 0.02 \\
\hline Obs. & 17 & 17 & 17 & 17 & 17 & 17 & 17 & 17 & 17 & 17 & 17 & 17 \\
\hline Heterof-stat & $\begin{array}{r}0.72 \\
{[0.56]} \\
\end{array}$ & $\begin{array}{r}0.38 \\
{[0.77]} \\
\end{array}$ & $\begin{array}{r}1.54 \\
{[0.25]} \\
\end{array}$ & $\begin{array}{r}0.77 \\
{[0.53]} \\
\end{array}$ & $\begin{array}{r}1.00 \\
{[0.42]} \\
\end{array}$ & $\begin{array}{r}1.41 \\
{[0.28]} \\
\end{array}$ & $\begin{array}{r}1.16 \\
{[0.35]} \\
\end{array}$ & $\begin{array}{r}0.70 \\
{[0.57]} \\
\end{array}$ & $\begin{array}{r}0.35 \\
{[0.79]} \\
\end{array}$ & $\begin{array}{r}1.09 \\
{[0.39]} \\
\end{array}$ & $\begin{array}{r}0.18 \\
{[0.91]} \\
\end{array}$ & $\begin{array}{r}0.36 \\
{[0.78]} \\
\end{array}$ \\
\hline $\mathrm{JB}_{\mathrm{N}}$ & $\begin{array}{r}0.43 \\
{[0.81]} \\
\end{array}$ & $\begin{array}{r}1.08 \\
{[0.58]} \\
\end{array}$ & $\begin{array}{r}0.86 \\
{[0.65]} \\
\end{array}$ & $\begin{array}{r}0.87 \\
{[0.65]} \\
\end{array}$ & $\begin{array}{r}0.26 \\
{[0.89]} \\
\end{array}$ & $\begin{array}{r}0.30 \\
{[0.86]} \\
\end{array}$ & $\begin{array}{r}1.49 \\
{[0.47]}\end{array}$ & $\begin{array}{r}1.69 \\
{[1.43]}\end{array}$ & $\begin{array}{r}4.16 \\
{[0.12]}\end{array}$ & $\begin{array}{r}2.30 \\
{[0.32]}\end{array}$ & $\begin{array}{r}1.83 \\
{[0.40]}\end{array}$ & $\begin{array}{r}1.93 \\
{[0.38]} \\
\end{array}$ \\
\hline LM test & $\begin{array}{r}1.47 \\
{[0.27]}\end{array}$ & $\begin{array}{r}1.33 \\
{[0.30]}\end{array}$ & $\begin{array}{r}1.89 \\
{[0.20]}\end{array}$ & $\begin{array}{r}2.69 \\
{[0.11]}\end{array}$ & $\begin{array}{r}1.41 \\
{[0.29]}\end{array}$ & $\begin{array}{r}0.76 \\
{[0.49]}\end{array}$ & $\begin{array}{r}1.16 \\
{[0.35]}\end{array}$ & $\begin{array}{r}1.36 \\
{[0.30]}\end{array}$ & $\begin{array}{r}4.45 \\
{[0.04]}\end{array}$ & $\begin{array}{r}7.18 \\
{[0.01]}\end{array}$ & $\begin{array}{r}0.26 \\
{[0.77]}\end{array}$ & $\begin{array}{r}0.14 \\
{[0.87]}\end{array}$ \\
\hline
\end{tabular}


Continues

\begin{tabular}{|c|c|c|c|c|c|c|c|c|c|c|c|c|}
\hline \multirow{4}{*}{ Exp.var } & \multicolumn{12}{|c|}{ Dependent variable } \\
\hline & \multicolumn{6}{|c|}{ Real wages growth rate: } & \multicolumn{6}{|c|}{ Returns on capital growth rate: } \\
\hline & \multicolumn{2}{|c|}{$\mathrm{S}_{\mathrm{B}}$} & \multicolumn{2}{|c|}{$\mathrm{S}_{\mathrm{L}}$} & \multicolumn{2}{|c|}{$\mathrm{S}_{\mathrm{NT}}$} & \multicolumn{2}{|c|}{$\mathrm{S}_{\mathrm{B}}$} & \multicolumn{2}{|c|}{$\mathrm{S}_{\mathrm{L}}$} & \multicolumn{2}{|c|}{$\mathrm{S}_{\mathrm{NT}}$} \\
\hline & (13) & $(14)$ & $(15)$ & $(16)$ & (17) & (18) & $(19)$ & $(20)$ & $(21)$ & $(22)$ & $(23)$ & $(24)$ \\
\hline Intercept & $\begin{array}{l}-16.62 \\
{[-0.81]}\end{array}$ & $\begin{array}{l}-24.34 \\
{[-0.96]}\end{array}$ & $\begin{array}{r}1.72 \\
{[0.88]}\end{array}$ & $\begin{array}{r}-7.84 \\
{[-0.55]}\end{array}$ & $\begin{array}{r}1.90 \\
{[0.14]}\end{array}$ & $\begin{array}{r}-0.02 \\
{[-0.01]}\end{array}$ & $\begin{array}{r}-6.96 \\
{[-0.12]}\end{array}$ & $\begin{array}{l}23.90 \\
{[0.50]}\end{array}$ & $\begin{array}{l}-51.56 \\
{[-0.46]}\end{array}$ & $\begin{array}{r}4.23 \\
{[0.04]}\end{array}$ & $\begin{array}{l}-24.87 \\
{[-0.72]}\end{array}$ & $\begin{array}{r}-8.51 \\
{[-0.28]}\end{array}$ \\
\hline Oil p. GR & $\begin{array}{r}-0.17 \\
{[-1.33]}\end{array}$ & $\begin{array}{r}-0.15 \\
{[-1.20]}\end{array}$ & $\begin{array}{r}-0.05 \\
{[-0.69]}\end{array}$ & $\begin{array}{r}-0.04 \\
{[-0.59]}\end{array}$ & $\begin{array}{r}-0.15^{*} \\
{[-1.79]}\end{array}$ & $\begin{array}{r}-0.14 \\
{[-1.76]}\end{array}$ & $\begin{array}{l}0.74^{* *} \\
{[3.49]}\end{array}$ & $\begin{array}{c}0.71^{* *} \\
{[3.39]}\end{array}$ & $\begin{array}{l}-1.13^{* *} \\
{[-2.69]}\end{array}$ & $\begin{array}{l}-1.16^{* *} \\
{[-2.69]}\end{array}$ & $\begin{array}{c}-0.57^{* *} \\
{[-4.47]}\end{array}$ & $\begin{array}{c}-0.58^{* * *} \\
{[-4.41]}\end{array}$ \\
\hline $\begin{array}{l}\text { Economic } \\
\text { crisis }\end{array}$ & $\begin{array}{r}-8.00 \\
{[-0.77]}\end{array}$ & $\begin{array}{r}-7.63 \\
{[-0.77]}\end{array}$ & $\begin{array}{r}-8.29 \\
{[-1.42]}\end{array}$ & $\begin{array}{r}-9.69 \\
{[-1.77]}\end{array}$ & $\begin{array}{r}-7.87 \\
{[-1.15]}\end{array}$ & $\begin{array}{r}-8.18 \\
{[-1.26]}\end{array}$ & $\begin{array}{r}7.49 \\
{[0.43]}\end{array}$ & $\begin{array}{l}10.96 \\
{[0.65]}\end{array}$ & $\begin{array}{r}1.54 \\
{[0.04]}\end{array}$ & $\begin{array}{r}6.81 \\
{[0.85]}\end{array}$ & $\begin{array}{l}12.69 \\
{[1.21]}\end{array}$ & $\begin{array}{l}14.17 \\
{[1.33]}\end{array}$ \\
\hline REER & $\begin{array}{r}0.16 \\
{[0.79]}\end{array}$ & & $\begin{array}{r}0.01 \\
{[0.02]}\end{array}$ & & $\begin{array}{r}-0.01 \\
{[-0.03]}\end{array}$ & & $\begin{array}{r}-0.03 \\
{[-0.05]}\end{array}$ & & $\begin{array}{r}0.40 \\
{[0.41]}\end{array}$ & & $\begin{array}{r}0.15 \\
{[0.50]}\end{array}$ & \\
\hline NEER & & $\begin{array}{r}0.26 \\
{[0.94]}\end{array}$ & & $\begin{array}{r}0.11 \\
{[0.70]}\end{array}$ & & $\begin{array}{r}0.02 \\
{[0.10]}\end{array}$ & & $\begin{array}{r}-0.37 \\
{[-0.72]}\end{array}$ & & $\begin{array}{r}-0.11 \\
{[-0.11]}\end{array}$ & & $\begin{array}{r}0.01 \\
{[0.02]}\end{array}$ \\
\hline $\mathrm{R}^{2}$ & 0.13 & 0.14 & 0.13 & 0.16 & 0.17 & 0.17 & 0.56 & 0.58 & 0.49 & 0.48 & 0.77 & 0.77 \\
\hline Adj. $R^{2}$ & -0.07 & -0.06 & -0.07 & -0.04 & -0.02 & -0.01 & 0.38 & 0.40 & 0.27 & 0.26 & 0.67 & 0.67 \\
\hline Obs. & 17 & 17 & 17 & 17 & 17 & 17 & 11 & 11 & 11 & 11 & 11 & 11 \\
\hline F-stat. & 0.63 & 0.70 & 0.65 & 0.80 & 0.90 & 0.90 & 3.01 & 3.26 & 2.21 & 2.15 & 7.87 & 7.65 \\
\hline Prob (F-stat) & 0.61 & 0.57 & 0.60 & 0.52 & 0.47 & 0.47 & 0.10 & 0.09 & 0.17 & 0.18 & 0.01 & 0.01 \\
\hline Het.F-stat & $\begin{array}{r}1.37 \\
{[0.29]}\end{array}$ & $\begin{array}{r}0.28 \\
{[0.84]}\end{array}$ & $\begin{array}{r}1.22 \\
{[0.34]}\end{array}$ & $\begin{array}{r}0.33 \\
{[0.80]}\end{array}$ & $\begin{array}{r}1.64 \\
{[0.23]}\end{array}$ & $\begin{array}{r}0.30 \\
{[0.82]}\end{array}$ & $\begin{array}{r}1.29 \\
{[0.35]}\end{array}$ & $\begin{array}{r}0.62 \\
{[0.63]}\end{array}$ & $\begin{array}{r}2.44 \\
{[0.86]}\end{array}$ & $\begin{array}{r}0.25 \\
{[0.85]}\end{array}$ & $\begin{array}{r}2.51 \\
{[0.14]}\end{array}$ & $\begin{array}{r}1.22 \\
{[0.40]}\end{array}$ \\
\hline$J B_{N}$ & $\begin{array}{r}2.55 \\
{[0.28]}\end{array}$ & $\begin{array}{r}1.10 \\
{[0.58]}\end{array}$ & $\begin{array}{r}0.57 \\
{[0.75]}\end{array}$ & $\begin{array}{r}0.58 \\
{[0.75]}\end{array}$ & $\begin{array}{r}8.45 \\
{[0.01]}\end{array}$ & $\begin{array}{r}7.75 \\
{[0.02]}\end{array}$ & $\begin{array}{r}0.45 \\
{[0.80]}\end{array}$ & $\begin{array}{r}0.71 \\
{[0.70]}\end{array}$ & $\begin{array}{r}0.72 \\
{[0.70]}\end{array}$ & $\begin{array}{r}0.39 \\
{[0.82]}\end{array}$ & $\begin{array}{r}0.33 \\
{[0.85]}\end{array}$ & $\begin{array}{r}0.43 \\
{[0.81]}\end{array}$ \\
\hline LM test & $\begin{array}{r}4.54 \\
{[0.04]}\end{array}$ & $\begin{array}{r}4.28 \\
{[0.04]}\end{array}$ & $\begin{array}{r}1.58 \\
{[0.25]}\end{array}$ & $\begin{array}{r}1.08 \\
{[0.37]}\end{array}$ & $\begin{array}{r}1.08 \\
{[0.37]}\end{array}$ & $\begin{array}{r}1.05 \\
{[0.38]}\end{array}$ & $\begin{array}{r}0.19 \\
{[0.84]}\end{array}$ & $\begin{array}{r}0.19 \\
{[0.83]}\end{array}$ & $\begin{array}{r}6.34 \\
{[0.04]}\end{array}$ & $\begin{array}{r}6.24 \\
{[0.04]}\end{array}$ & $\begin{array}{r}0.20 \\
{[0.83]}\end{array}$ & $\begin{array}{r}0.16 \\
{[0.86]}\end{array}$ \\
\hline
\end{tabular}

Note: 1) PC denotes percentage change; 2) the bold coefficients emphasize the significant results; 3 ) the symbols *, ${ }^{* *}$, and ${ }^{* * *}$ indicate statistical significance at $10 \%, 5 \%$, and $1 \%$ levels, respectively; 4 ) the numbers in the brackets are the corresponding $t$-statistics; 5 ) the estimations do not include degrees of freedom adjustment for standard errors and covariance; 6) numbers were rounded to the second decimal point for compactness; 7) Het. F-stat denotes heteroscedasticity test based on Breusch - Pagan - Godfrey method, JBN denoted the Jaque - Bera normality test results, and the LM test is the Lagrange Multiplier test for serial correlation. The numbers in the brackets indicate the p-values.

\subsection{Resource movement effect}

Table 4 reports the results of the resource movement effect of Dutch disease in Azerbaijan. The models largely reflected higher goodness of fit in the left-hand side of the table where output growth rates were tested (considering higher R-squared and adjusted R-square values compared to the models with employment growth rates as dependent variables). On the other hand, both models with the employment growth rate in the booming sectors as dependent variables had the lowest adjusted R-squared values. The observation number was 17 for all models.

There are trends in the estimation results that agree with the Dutch disease model. Some examples of these trends include a negative association between the output growth rates of booming sectors and non-tradable sectors and a negative association between lagging and nontradable sectors. Moreover, population income as measured by AZN and USD exhibited significant results with the output of lagging and non-tradable sectors. 
Resource movement effect in Azerbaijan, OLS results, 2000-2018

Table 4.

\begin{tabular}{|c|c|c|c|c|c|c|c|c|c|c|c|c|}
\hline \multirow{4}{*}{ Exp.var } & \multicolumn{12}{|c|}{ Dependent variable } \\
\hline & \multicolumn{6}{|c|}{ Output growth rate: } & \multicolumn{6}{|c|}{ Employment growth rate: } \\
\hline & \multicolumn{2}{|c|}{$\mathrm{S}_{\mathrm{B}}$} & \multicolumn{2}{|c|}{$\mathrm{S}_{\mathrm{L}}$} & \multicolumn{2}{|c|}{$\mathrm{S}_{\mathrm{NT}}$} & \multicolumn{2}{|c|}{$\mathrm{S}_{\mathrm{B}}$} & \multicolumn{2}{|c|}{$\mathrm{S}_{\mathrm{L}}$} & \multicolumn{2}{|c|}{$\mathrm{S}_{\mathrm{NT}}$} \\
\hline & $(25)$ & $(26)$ & (27) & (28) & (29) & $(30)$ & $(31)$ & $(32)$ & (33) & (34) & (35) & $(36)$ \\
\hline Intercept & $\begin{array}{r}0.10 \\
{[0.02]}\end{array}$ & $\begin{array}{r}-0.09 \\
{[-0.02]}\end{array}$ & $\begin{array}{r}-0.35 \\
{[-0.27]}\end{array}$ & $\begin{array}{r}-0.36 \\
{[-0.25]}\end{array}$ & $\begin{array}{r}-0.48 \\
{[-0.16]}\end{array}$ & $\begin{array}{r}-0.24 \\
{[-0.14]}\end{array}$ & $\begin{array}{r}0.68 \\
{[0.76]}\end{array}$ & $\begin{array}{r}0.64 \\
{[0.76]}\end{array}$ & $\begin{array}{r}0.01 \\
{[0.02]}\end{array}$ & $\begin{array}{r}-0.01 \\
{[-0.03]}\end{array}$ & $\begin{array}{r}-0.01 \\
{[-0.08]}\end{array}$ & $\begin{array}{r}-0.01 \\
{[-0.09]}\end{array}$ \\
\hline $\mathrm{S}_{\mathrm{B}}-\mathrm{GR}$ & & & $\begin{array}{r}-0.09 \\
{[-0.25]}\end{array}$ & $\begin{array}{r}-0.21 \\
{[-0.50]}\end{array}$ & $\begin{array}{r}1.19 \\
{[1.50]}\end{array}$ & $\begin{array}{r}0.23 \\
{[0.46]}\end{array}$ & & & $\begin{array}{r}8.91 \\
{[0.01]}\end{array}$ & $\begin{array}{r}0.02 \\
{[0.56]}\end{array}$ & $\begin{array}{r}-0.01 \\
{[-0.45]}\end{array}$ & $\begin{array}{r}-0.01 \\
{[-0.10]}\end{array}$ \\
\hline $\mathrm{S}_{\mathrm{L}}-\mathrm{GR}$ & $\begin{array}{r}-0.10 \\
{[-0.01]}\end{array}$ & $\begin{array}{r}2.12 \\
{[0.19]}\end{array}$ & & & $\begin{array}{r}-9.45^{*} \\
{[-2.07]}\end{array}$ & $\begin{array}{r}-3.63 \\
{[-1.29]}\end{array}$ & $\begin{array}{r}0.01 \\
{[0.01]}\end{array}$ & $\begin{array}{r}0.94 \\
{[0.56]}\end{array}$ & & & $\begin{array}{l}-0.28^{* *} \\
{[-2.58]}\end{array}$ & $\begin{array}{l}-0.34^{* *} \\
{[-2.90]}\end{array}$ \\
\hline $\mathrm{S}_{\mathrm{NT}}-\mathrm{GR}$ & $\begin{array}{r}-41.66^{* *} \\
{[-2.19]}\end{array}$ & $\begin{array}{r}-43.59^{* *} \\
{[-2.31]}\end{array}$ & $\begin{array}{r}-6.03 \\
{[-1.62]}\end{array}$ & $\begin{array}{l}-9.04^{* *} \\
{[-2.27]}\end{array}$ & & & $\begin{array}{r}-1.36 \\
{[-0.45]}\end{array}$ & $\begin{array}{r}-0.29 \\
{[-0.10]}\end{array}$ & $\begin{array}{l}-0.99^{* *} \\
{[-2.58]}\end{array}$ & $\begin{array}{l}-0.96^{* *} \\
{[-2.90]}\end{array}$ & & \\
\hline Inc.AZN & $\begin{array}{r}0.78 \\
{[1.24]}\end{array}$ & & $\begin{array}{l}0.46^{* * *} \\
{[3.30]}\end{array}$ & & $\begin{array}{r}0.67^{* *} \\
{[2.257]}\end{array}$ & & $\begin{array}{r}0.06 \\
{[0.62]}\end{array}$ & & $\begin{array}{r}-0.02 \\
{[-1.14]}\end{array}$ & & $\begin{array}{l}-0.01 * * \\
{[-2.07]}\end{array}$ & \\
\hline Inc.USD & & $\begin{array}{r}0.47 \\
{[1.10]}\end{array}$ & & $\begin{array}{l}0.23^{* *} \\
{[2.17]}\end{array}$ & & $\begin{array}{l}0.89^{* * *} \\
{[6.90]}\end{array}$ & & $\begin{array}{r}0.10 \\
{[1.56]}\end{array}$ & & $\begin{array}{l}-0.02^{* *} \\
{[-2.21]}\end{array}$ & & $\begin{array}{l}-0.01 * * \\
{[-1.83]}\end{array}$ \\
\hline $\mathrm{R}^{2}$ & 0.44 & 0.43 & 0.56 & 0.43 & 0.44 & 0.80 & 0.06 & 0.16 & 0.28 & 0.40 & 0.41 & 0.38 \\
\hline Adj. $R^{2}$ & 0.31 & 0.29 & 0.45 & 0.30 & 0.31 & 0.77 & -0.15 & -0.03 & 0.12 & 0.26 & 0.27 & 0.24 \\
\hline Obs. & 17 & 17 & 17 & 17 & 17 & 17 & 17 & 17 & 17 & 17 & 17 & 17 \\
\hline F-stat. & 3.36 & 3.22 & 5.40 & 3.25 & 3.42 & 18.37 & 0.30 & 0.84 & 1.72 & 2.90 & 2.98 & 2.66 \\
\hline $\begin{array}{l}\text { Prob } \\
\text { (F-stat) }\end{array}$ & 0.05 & 0.05 & 0.45 & 0.06 & 0.04 & 0.00 & 0.83 & 0.49 & 0.21 & 0.07 & 0.07 & 0.09 \\
\hline Het.F-stat & $\begin{array}{r}1.04 \\
{[0.35]}\end{array}$ & $\begin{array}{r}0.46 \\
{[0.65]}\end{array}$ & $\begin{array}{r}0.81 \\
{[0.65]}\end{array}$ & $\begin{array}{r}0.16 \\
{[0.97]}\end{array}$ & $\begin{array}{r}0.76 \\
{[0.47]}\end{array}$ & $\begin{array}{r}1.04 \\
{[0.77]}\end{array}$ & $\begin{array}{r}0.74 \\
{[0.83]}\end{array}$ & $\begin{array}{r}0.56 \\
{[0.58]}\end{array}$ & $\begin{array}{r}1.68 \\
{[0.56]}\end{array}$ & $\begin{array}{r}0.72 \\
{[0.49]}\end{array}$ & $\begin{array}{r}1.04 \\
{[0.35]}\end{array}$ & $\begin{array}{r}1.15 \\
{[0.31]}\end{array}$ \\
\hline $\mathrm{JB}_{\mathrm{N}}$ & $\begin{array}{r}0.55 \\
{[0.76]}\end{array}$ & $\begin{array}{r}0.62 \\
{[0.73]}\end{array}$ & $\begin{array}{r}0.31 \\
{[0.86]}\end{array}$ & $\begin{array}{r}0.24 \\
{[0.89]}\end{array}$ & $\begin{array}{r}0.22 \\
{[0.99]}\end{array}$ & $\begin{array}{r}0.57 \\
{[0.75]}\end{array}$ & $\begin{array}{r}0.47 \\
{[0.79]}\end{array}$ & $\begin{array}{r}0.34 \\
{[0.84]}\end{array}$ & $\begin{array}{r}0.23 \\
{[0.89]}\end{array}$ & $\begin{array}{r}0.38 \\
{[0.83]}\end{array}$ & $\begin{array}{r}1.57 \\
{[0.46]}\end{array}$ & $\begin{array}{r}1.54 \\
{[0.46]}\end{array}$ \\
\hline LM test & $\begin{array}{r}0.77 \\
{[0.36]}\end{array}$ & $\begin{array}{r}0.21 \\
{[0.79]}\end{array}$ & $\begin{array}{r}1.77 \\
{[0.12]}\end{array}$ & $\begin{array}{r}0.77 \\
{[0.37]}\end{array}$ & $\begin{array}{r}0.55 \\
{[0.50]}\end{array}$ & $\begin{array}{r}1.92 \\
{[0.10]}\end{array}$ & $\begin{array}{r}0.51 \\
{[0.52]}\end{array}$ & $\begin{array}{r}0.55 \\
{[0.49]}\end{array}$ & $\begin{array}{r}0.89 \\
{[0.31]}\end{array}$ & $\begin{array}{r}1.13 \\
{[0.23]}\end{array}$ & $\begin{array}{r}4.06 \\
{[0.03]}\end{array}$ & $\begin{array}{r}1.56 \\
{[0.14]}\end{array}$ \\
\hline
\end{tabular}

Note: 1) PC denotes percentage change; 2) the bold coefficients emphasize the significant results; 3 ) the symbols *, **, and ${ }^{* * *}$ indicate statistical significance at 10\%, 5\%, and $1 \%$ levels, respectively; 4) the numbers in the brackets are the corresponding $t$-statistics; 5 ) The left side of the table employs output growth rates such as $\mathrm{S}_{\mathrm{B}}-\mathrm{PC}, \mathrm{S}_{\mathrm{L}}-\mathrm{PC}, \mathrm{S}_{\mathrm{NT}}-\mathrm{PC}$ as independent variables; 6 ) The right side of the table employs employment growth rates as independent variables such as $\mathrm{S}_{\mathrm{B}}-\mathrm{PC}, \mathrm{S}_{\mathrm{L}}-\mathrm{PC}, \mathrm{S}_{\mathrm{NT}}-\mathrm{PC}$; 7) The estimations do not include degrees of freedom adjustment for standard errors and covariance; 8) All numbers were rounded to the second decimal point for compactness; 9) Het.F-stat denotes heteroscedasticity test based on Breusch - Pagan - Godfrey method, JB $B_{N}$ denoted the Jaque - Bera normality test results, and the LM test is the Lagrange Multiplier test for serial correlation. The numbers in the brackets indicate the $p$-values.

The employment growth rate in $\mathrm{S}_{\mathrm{L}}$ was negatively associated with $\mathrm{S}_{\mathrm{NT}}$ and vice versa. Also, like the left-hand side of Table 4, population income had significant indicators only for lagging and non-tradable sectors.

Although none of the intercepts and percentages changes in $S_{B}$ had a significant effect on output and employment growth rates, the signs of the coefficients were consistent with the general theoretical framework of the Dutch disease model. Negative coefficients of the intercept indicate that ceteris paribus, the output and employment growth rates tend to decline over time. The output and employment growth rate in $S_{B}$ were inversely associated with the $S_{L}$ and $S_{\mathrm{NT}}$. 
Resource movement models contain homoscedastic and normally distributed residuals, and only one model - model number 35 showed serial correlation.

\subsection{Spending effect}

The spending effect illustrated in Table 5 produced considerably higher significant findings than the resource movement effect. Its R-squared values were larger than under resource movement equations.

Growth rates in CPI were positively and significantly associated with MPC, but the differrence in significance was higher in the first model where government spending was tested in billions of USD instead of percentage share of GDP. Likewise, MPC and population income in USD were positively and significantly associated with CPI growth rates. Government spending in billions of USD and as a share in GDP were also positively and significantly associated with CPI growth rates (higher significance for the former). Interestingly, the output of the non-tradable sectors was negatively and significantly associated with CPI.

It is argued that the most profound signs of the spending effect are the price levels in nontradable sectors and the exchange rate. That is why CPI, REER, and NEER growth rates were tested for interconnections. No significant outcomes were found between MPC, $\mathrm{S}_{\mathrm{NT}}$ output, and REER and NEER growth rates. However, population income in USD positively and significantly impacted REER and NEER growth rates in the first model. There were significant and negative coefficients for government spending in connection with REER and NEER growth rates.

Table 5.

Spending effect in Azerbaijan, OLS results, 2000-2018

\begin{tabular}{|c|c|c|c|c|c|c|}
\hline \multirow[b]{3}{*}{ Exp.var. } & \multicolumn{6}{|c|}{ Dependent variable } \\
\hline & \multicolumn{2}{|c|}{ CPI-GR } & \multicolumn{2}{|c|}{ REER-GR } & \multicolumn{2}{|c|}{ NEER-GR } \\
\hline & $(37)$ & (38) & (39) & $(40)$ & $(41)$ & $(42)$ \\
\hline Intercept & $\begin{array}{r}-0.23 \\
{[-0.27]}\end{array}$ & $\begin{array}{r}-0.40 \\
{[-0.24]}\end{array}$ & $\begin{array}{r}-0.01 \\
{[-0.01]}\end{array}$ & $\begin{array}{r}0.15 \\
{[0.07]}\end{array}$ & $\begin{array}{r}-0.17 \\
{[-0.07]}\end{array}$ & $\begin{array}{r}-0.02 \\
{[-0.01]}\end{array}$ \\
\hline MPC & $\begin{array}{l}0.11^{* * *} \\
{[5.13]}\end{array}$ & $\begin{array}{r}0.09^{*} \\
{[2.17]}\end{array}$ & $\begin{array}{r}0.01 \\
{[0.34]}\end{array}$ & $\begin{array}{r}0.04 \\
{[0.78]}\end{array}$ & $\begin{array}{r}0.06 \\
{[1.02]}\end{array}$ & $\begin{array}{r}0.08 \\
{[1.32]}\end{array}$ \\
\hline $\mathrm{S}_{\mathrm{NT}}$ output & $\begin{array}{c}-1.07^{* * *} \\
{[-7.61]}\end{array}$ & $\begin{array}{c}-1.26^{* * *} \\
{[-4.83]}\end{array}$ & $\begin{array}{r}-0.05 \\
{[-0.15]}\end{array}$ & $\begin{array}{r}0.04 \\
{[0.11]}\end{array}$ & $\begin{array}{r}-0.18 \\
{[-0.45]}\end{array}$ & $\begin{array}{r}-0.07 \\
{[-0.17]}\end{array}$ \\
\hline Population income in USD & $\begin{array}{l}0.67^{* * *} \\
{[4.18]}\end{array}$ & $\begin{array}{l}1.35^{* * *} \\
{[4.91]}\end{array}$ & $\begin{array}{l}1.00^{* *} \\
{[2.49]}\end{array}$ & $\begin{array}{r}0.50 \\
{[1.42]}\end{array}$ & $\begin{array}{l}1.00^{* *} \\
{[2.18]}\end{array}$ & $\begin{array}{r}0.48 \\
{[1.14]}\end{array}$ \\
\hline Gov. spen. - billions USD & $\begin{array}{l}0.48^{* * *} \\
{[8.64]}\end{array}$ & & $\begin{array}{c}-0.32^{* *} \\
{[-2.31]}\end{array}$ & & $\begin{array}{c}-0.34^{*} \\
{[-2.17]}\end{array}$ & \\
\hline Gov. spen. - \% share of GDP & & $\begin{array}{l}0.30^{* *} \\
{[2.91]}\end{array}$ & & $\begin{array}{c}-0.34^{* *} \\
{[-2.61]}\end{array}$ & & $\begin{array}{r}-0.31^{*} \\
{[-1.96]}\end{array}$ \\
\hline $\mathrm{R}^{2}$ & 0.91 & 0.67 & 0.63 & 0.65 & 0.51 & 0.49 \\
\hline Adj. $\mathrm{R}^{2}$ & 0.88 & 0.56 & 0.51 & 0.54 & 0.35 & 0.32 \\
\hline Obs. & 17 & 17 & 17 & 17 & 17 & 17 \\
\hline
\end{tabular}




\begin{tabular}{|c|c|c|c|c|c|c|}
\hline \multirow[b]{3}{*}{ Exp.var. } & \multicolumn{6}{|c|}{ Dependent variable } \\
\hline & \multicolumn{2}{|c|}{ CPI-GR } & \multicolumn{2}{|c|}{ REER-GR } & \multicolumn{2}{|c|}{ NEER-GR } \\
\hline & (37) & (38) & (39) & $(40)$ & (41) & $(42)$ \\
\hline F-stat. & 30.0 & 6.18 & 5.16 & 5.70 & 3.11 & 2.87 \\
\hline Prob(F-stat) & 0.00 & 0.01 & 0.01 & 0.01 & 0.06 & 0.07 \\
\hline Het.F-stat & $\begin{array}{r}0.41 \\
{[0.82]}\end{array}$ & $\begin{array}{r}0.27 \\
{[0.98]}\end{array}$ & $\begin{array}{r}0.35 \\
{[0.97]}\end{array}$ & $\begin{array}{r}0.56 \\
{[0.94]}\end{array}$ & $\begin{array}{r}0.29 \\
{[0.97]}\end{array}$ & $\begin{array}{r}0.47 \\
{[0.68]}\end{array}$ \\
\hline$J B_{N}$ & $\begin{array}{r}3.24 \\
{[0.20]}\end{array}$ & $\begin{array}{r}1.23 \\
{[0.54]}\end{array}$ & $\begin{array}{r}1.57 \\
{[0.45]}\end{array}$ & $\begin{array}{r}1.47 \\
{[0.48]}\end{array}$ & $\begin{array}{r}3.31 \\
{[0.19]}\end{array}$ & $\begin{array}{r}2.26 \\
{[0.32]}\end{array}$ \\
\hline LM test & $\begin{array}{r}1.03 \\
{[0.23]}\end{array}$ & $\begin{array}{r}1.23 \\
{[0.17]}\end{array}$ & $\begin{array}{r}1.70 \\
{[0.10]}\end{array}$ & $\begin{array}{r}2.86 \\
{[0.04]}\end{array}$ & $\begin{array}{r}2.33 \\
{[0.06]}\end{array}$ & $\begin{array}{r}2.55 \\
{[0.05]}\end{array}$ \\
\hline
\end{tabular}

Note: 1) the bold coefficients emphasize the significant results; 2 ) the symbols ${ }^{*},{ }^{* *}$, and ${ }^{* * *}$ indicate statistical significance at $10 \%, 5 \%$, and $1 \%$ levels, respectively; 3 ) the numbers in the brackets are the corresponding t-statistics; 4) MPC is marginal propensity to consume; 5) $\mathrm{S}_{\mathrm{NT}}$ means non-tradable sectors; 6) the estimations do not include degrees of freedom adjustment for standard errors and covariance; and 7) the numbers were rounded to the second decimal point to be compact; 8) Het. F-stat denotes heteroscedasticity test based on Breusch - Pagan - Godfrey method, JBN denoted the Jaque - Bera normality test results, and the LM test is the Lagrange Multiplier test for serial correlation. The numbers in the brackets indicate the $p$-values.

Excluding model 40, all residuals of the analysis presented homoscedastic and normally distributed residuals without any serial correlation (see the lower part of Table 5 for the applied tests).

\subsection{Stability tests}

Overall, this research estimated 42 equations. To test the stability of the obtained coeffcients, 84 stability tests were conducted. Half of the tests included CUSUM (cumulative sum) tests; the other half were CUSUM square tests of residuals. Table 6 provides the generalized results.

Table 6.

Stability test results, the total number of models that were within the $5 \%$ significance bound

\begin{tabular}{|c|c|c|c|c|}
\hline & \multicolumn{2}{|c|}{$\begin{array}{l}\text { Number of stable } \\
\text { coefficients }\end{array}$} & \multirow{2}{*}{$\begin{array}{c}\text { Number } \\
\text { of unstable } \\
\text { coefficients }\end{array}$} & \multirow[t]{2}{*}{ Total } \\
\hline & CUSUM & CUSUMSQ & & \\
\hline $\begin{array}{l}\text { Impact of oil prices, REER, NEER } \\
\text { and economic crisis }\end{array}$ & 24 & 22 & 2 & 48 \\
\hline Resource movement effect & 12 & 8 & 4 & 24 \\
\hline Spending effect & 5 & 5 & 2 & 12 \\
\hline Total & 41 & 35 & 8 & 84 \\
\hline
\end{tabular}

Note: The number of unstable coefficients totals both the CUSUM and CUSUM tests of squares. 
Out of 84 test results, 76 were stable in terms of CUSUM and CUSUM square tests, which correspond to $90.5 \%$ of the total coefficients. In other words, OLS estimations were robust and responsive to general trustworthiness within multivariate linear regression.

To address the multicollinearity issue, centered Variance Inflation Factors (VIF) have been reported in Table A3. VIF detects the degree of multicollinearity among the explanatory variables, providing the level of degradations of the estimation [Freud et al., 2003]. Hence, a widely accepted rule is that VIF should not exceed the value of 10 [Belsley et al., 1980]. Table A3 reports «+» if the calculated VIF did not exceed 10 and «-» if VIF exceeded 10. According to the results, there is no multicollinearity in the independent variables among the designed models of this paper.

Finally, to understand if the estimations are reliable or not, the Ramsey Reset test has been conducted to test if there are any equation or model misspecifications. The number of fitted terms was one. Out of the estimated 42 models, only models 5, 6, and 36 exhibited specification errors (see Table A3). To have more interpretation possibility, F-values and t-statistics have also been reported which was recommended by Robinson and Schumacker (2009) for the case of VIF but also useful for the Ramsey Reset test.

Thus, the overall reliability degree of the calculations is high because of stationary data, stable coefficients (CUSUM and CUSUMSQ), lack of multicollinearity, and low amount of model specification errors. Also, the majority of the residuals are normally distributed and homoscedastic. Excluding minor examples of the models with serial correlations, models predict a reliable picture of the Azerbaijan economy in terms of Dutch disease signs.

\section{Discussion}

The current study aimed to answer the following research question: does the economy of Azerbaijan demonstrate the signs of Dutch disease in line with the theoretical expectations of the core model? The findings from this study suggest that the Azerbaijan economy partially exhibits the Dutch disease signs that were modeled by Corden and Neary (1982) and Corden (1984). The research design allows us to connect the overall effects of oil prices, REER, NEER and economic crisis periods with the resource movement and spending effect of Dutch disease syndrome.

First, the study tried to demonstrate the sectoral distribution of the impact of oil prices, REER, NEER, and economic crisis periods. Even without considering resource movement and spending effects, any possible negative effect of oil prices, REER, NEER, and economic crisis on lagging sectors indicates the signs of Dutch disease channels. There were significant effects between the output growth rates and changes in oil prices.

Booming sectors were significantly and positively affected by the changes in oil prices. These findings are consistent with the descriptive observation of the extractive industries' output. In other words, the booming period was between 2007-2011 in Azerbaijan; however, the country experienced oil-based economic development since the late 1990s. The post-2003 was golden age for oil-exporters (see Fig.2a for oil prices) highly stimulated the output growth in oil and gas extraction. However, if the booming sectors lag the other tradable sectors, Dutch disease effects occur. Empirically speaking, changes in oil prices did not negatively impact the lagging sectors, as the output growth rates in lagging sectors did not exhibit any significant and negative associations with oil prices or exchange rate (see Table 3 ). These points suggests that the spending effect of Dutch disease via oil prices and exchange rate channels is more potent than the resource movement effect, which has been reported by Hasanov (2013). 
Fall in the output of $\mathrm{S}_{\mathrm{NT}}$ might indicate indirect de-industrialization of the resource movement because labor resources might shift to booming sectors from non-tradable sectors. Employment growth rates in $\mathrm{S}_{\mathrm{NT}}$ were negatively and significantly associated with the changes in the oil prices and the intercept but positively associated with NEER. There is a possibility that indirect de-industrialization and spending effect might occur together, although the estimations on Table 3 are not sufficient to solely support conclusions about indirect de-industrialization or spending effect.

Corden and Neary (1982) have argued that the effect of a boom on the real wage is uncertain if resource movement and spending effect occur jointly. The only significant interaction was between changes in oil prices and real wage growth rate in non-tradable sectors (see Table 3). Additionally, meaningful coefficients theoretically point to the relevance of the estimations regarding real wages even if they are insignificant. For example, changes in oil prices were negatively associated with lagging and non-tradable sectors, and economic crisis periods negatively affected real wages in all sectors. REER and NEER variables were ambiguous to determine the relational direction with the real wages.

Theoretical expectations were fulfilled according to the results for the returns on capital. Oil prices were positively and significantly associated with the returns on capital in booming sectors. As output boomed and oil prices favored extraction and production, profit margins increased. Figure 1, panel c demonstrates how FDI flowed more into oil sectors than in lagging sectors. Negative and significant findings for the lagging and non-tradable sectors with the changes in oil prices signify the negative effects of oil and gas sectors on the returns on capital. Thus, under these conditions, Dutch disease effects form a market narrative that illustrates where to invest. As the profitability of assets is higher in booming sectors, there will be less incentive to invest in manufacturing or agriculture sectors.

The above-mentioned dynamics illustrated a picture where capital resources favored oil and gas sectors and where there is a possibility of indirect de-industrialization and spending effects. However, the resource movement effect of the Dutch disease model emphasizes labor resources. The estimation in Table 3 could not conclude any negative and significant association between REER, NEER, and employment growth among the lagging or non-tradable sectors. However, a negative and statistically significant link between $S_{N T}$ and $S_{L}$ and vice versa in Table 4 might indicate the shift of labor from lagging sectors to non-tradable sectors. According to the original theory [Corden, Neary, 1982], if labor resources shift from non-tradable sectors to booming sectors or from lagging sectors to non-tradable sectors, there is indirect de-industrialization of the resource movement effect. Meanwhile, no significant association was found in terms of direct de-industrialization of the resource movement effect because there is no statistically significant and negative outcome from lagging sectors to booming sectors that could indicate possible shifts of the labor resources.

The resource movement effect is mainly about the changes of labor and capital between the macroeconomic sectors. Nonetheless, the decision of the labor resources to move is based on the incentives related to the income signals in a booming sector or non-tradable sector (which the Dutch disease model is particularly interested in). Wages extensively determine the income level of the population. The side role of income might have additional explanatory power in estimating the resource movement effect. That is why the constructed models also employed population income data in terms of AZN and USD. It should be noted that the USD time series also incorporates devaluation effects for 2014-2015. 
Therefore, Table 4 illustrates that population income in AZN and USD are in a positive association with the output growth rates in $\mathrm{S}_{\mathrm{L}}$ and $\mathrm{S}_{\mathrm{NT}}$. It can be speculated that, as disposable income level rises, consumers tend to spend their money on imported or locally produced tradable goods. Also, as depicted in Figure 2 panel b, the non-tradable sectors increased their role in the economy of Azerbaijan, which increased the demand for the labor in $\mathrm{S}_{\mathrm{NT}}$. Over time, most non-tradable sectors provided higher wages compared to the previous periods and other economic sectors. However, population income in terms of AZN only had a negative impact on the employment growth rate in $S_{\mathrm{NT}}$, but population income in USD harmed $\mathrm{S}_{\mathrm{L}}$ and $\mathrm{S}_{\mathrm{NT}}$. This is a surprising finding. A potential explanation is that the values of the coefficients are small, and highly aggregated variables might be inaccurate when subject to the OLS regressions.

The theoretical framework on Graph 2 emphasizes important points for tracking the spending effect: direct spending from the factor owners ${ }^{9}$, increased price levels and demand in $\mathrm{S}_{\mathrm{NT}}$, the movement of resources from $S_{B}$ and $S_{L}$ into $S_{N T}$, and real exchange rate appreciation. The analysis of spending effect in the Azerbaijan economy reveals that the post-boom period was accompanied by higher CPI that was determined by increased MPC, surged population income (in USD), and government spending (both in billions of USD and as a percentage share of GDP), see Table 4.

Thus, government spending in billions of USD and as a percentage share of GDP had a statistically significant impact on CPI growth rates, but REER and NEER growth rates were negatively impacted by government spending (see Table 4). Then, if we assume that government spending increases population income because there is increased employment in $\mathrm{S}_{\mathrm{NT}}$ due to the increased labor demand, those trends when combined with MPC illustrate the channels of the spending effect. According to the results in Table 4, increased population income alongside with the significant and positive MPC also increased CPI. However, real appreciations (measured by REER and NEER) were mainly determined by government spending in a statistically significant and negative way. Furthermore, population income in USD influenced REER and NEER growth rates positively. These aspects of the spending effect put it in an ambiguous position. On one hand, population income had a statistically significant impact on CPI, REER, and NEER. On the other hand, government spending had a statistically significant negative effect on REER and NEER indicators. This means that on one hand, the citizens' income (and possible spending) increase CPI, REER, and NEER, while on the other hand, the government's expenditure decreases those. Thus, government expenditures may not be consumer stimulating because they do not affect consumer-related indicators such as CPI, REER, and NEER in a theoretically expected way ${ }^{10}$. Overall, a higher amount of significant findings suggests that the spending effect has a stronger presence in the Azerbaijan economy than the resource movement effect.

Lastly, Pairwise Granger Causality tests by Granger (1969) (with 2 lags) supported a certain degree of the existence of Dutch disease in the Azerbaijan economy (see Table A4, A5, A6). As the REER Granger-cause $S_{\mathrm{NT}}$ output; $\mathrm{S}_{\mathrm{NT}}$ employment Granger-cause $\mathrm{S}_{\mathrm{B}}$ employment; CPI Granger-cause MPC, and lastly government spendings Granger-cause REER, we can argue that a set of benign conditions do exist to allow Dutch disease signs to emerge.

${ }^{9}$ In Azerbaijan's case, government is the source of the direct spending due to the country's nationalized oil and gas sectors.

10 In fact, the government's investments or expenditures are mainly infrastructure (i.e., Baku - Tbilisi Ceyhan pipeline or Baku - Tbilisi - Gars railway projects) or pertain to public entertainment (Eurovision song contest or Formula 1). 


\section{Limitations}

First, this analysis used highly aggregated annual data, which could affect accurate diagnostics. However, the overall relationship is still based on the core model of the theory, and the theoretical framework of the paper minimizes the inconclusiveness. Second, OLS regression does not provide wider implications for the causal relationship among the variables. Instead of multiple regression equations, further research should employ differences in the difference approach or separate regression estimations of the periods, such as before and after the crisis periods, to have a more accurate picture of Dutch disease effects. Furthermore, OLS is sensitive to the outliers, which can be overcome with an alternative estimation method called the Theil - Sen regression. Third, the sub-sectoral effects of Dutch disease must also be evaluated. Even the core model from Corden and Neary (1982) indicates the importance of the separation of the tradable sector into smaller components. One tradable sector might receive negative impacts from the booming sectors, the other might not. The difference between them would shed light on the Dutch disease effects from different perspectives and could help to clarify microeconomic aspects of the Dutch disease effects in the Azerbaijan economy that supplement the numerous macroeconomic studies.

Data availability presents another challenge. Official and public statistics enable the analysis of annual trends; however Dutch disease studies must be investigated alongside monthly or quarterly data to reveal the most important patterns that overlap with the theory. Furthermore, to increase accuracy at determining Dutch disease's effects on real wages, it is important to perform additional calculations related to the sectoral distribution of the real wages to address the highest possible relevance with the theoretical explanations from Corden and Neary (1982). This means that it is insufficient to adjust nominal wages to CPI to obtain real wages; it is also important to estimate one sector in terms of other sectors (for instance, manufacturing wages or lagging sectors' wages in terms of services or non-tradable sectors).

This paper is primarily interested in the signs and sizes of the estimated coefficients as indicators of Dutch disease's effects on Azerbaijan's macroeconomic sectors. The models were parsimonious and simplistic, and any conclusions from the research must be handled with great caution. That said, the Dutch disease hypothesis is still relevant for the Azerbaijan economy within the constructed theoretical framework and the applied linear multivariate OLS regressions.

\section{Concluding remarks}

The paper estimates resource movement and spending effects of Dutch disease theory in Azerbaijan between 2000-2018 utilizing multivariate linear OLS regressions. In terms of the resource movement effect, a negative association between the employment growth rates of lagging sectors and non-tradable sectors might indicate indirect de-industrialization. Moreover, population income as calculated by USD, which also includes devaluation effects, indicated a negative and significant relationship with the employment growth rate in the lagging and nontradable sectors. Across the background of commodity price slumps, decreased oil exports, and lowered population income, negative connections between lagging and non-tradable sectors point to the presence of resource movement effects, but the lack of such an inverse relationship with booming sectors undermine more conclusive statement about the presence of the resource movement effect. 
A positive and significant association between the output of non-tradable sectors together with the high MPC stemming from the increased population income and increased government spending could explain CPI growth rates. This indicates the CPI channel of spending effect, although REER and NEER growth rates were inversely correlated with the government spending but positively correlated with the income population. Overall, considering the limitations of the study, the generalizations should be dealt with great caution due to the aggregated nature of the analyzed variables. The paper opens a new path to analyze the Dutch disease syndrome in the Azerbaijan economy. Based on the limitations of the current study, new developments, and more comprehensive models, the Dutch disease can further be tracked in the Azerbaijan economy. Such research is key for producing useful policy adjustments. Otherwise, after the oil savings run out and oil production falls, weak volatility in the commodity markets can shake macroeconomic stability and lead to a deep economic recession.

\section{Appendix}

Augmented Dickey - Fuller Unit Root Test Results

\begin{tabular}{|c|c|c|c|c|c|c|}
\hline \multirow[t]{2}{*}{ Variable } & \multicolumn{3}{|c|}{ Level } & \multicolumn{3}{|c|}{$1^{\text {st }}$ difference } \\
\hline & Intercept & $\begin{array}{l}\text { Intercept } \\
\text { and Trend }\end{array}$ & $\begin{array}{l}\text { Without } \\
\text { Intercept } \\
\text { and Trend }\end{array}$ & Intercept & $\begin{array}{l}\text { Intercept } \\
\text { and Trend }\end{array}$ & $\begin{array}{c}\text { Without } \\
\text { Intercept } \\
\text { and Trend }\end{array}$ \\
\hline Oil_p_GR & $-3.07^{* *}$ & -3.19 & $-2.78^{* * *}$ & $-5.10^{* * *}$ & $-4.92^{* * *}$ & $-5.25^{* * *}$ \\
\hline REER & -1.25 & -1.14 & -0.30 & $-3.32^{* *}$ & -3.27 & $-3.43^{* * *}$ \\
\hline NEER & -1.23 & -1.34 & -0.83 & $-3.41^{* *}$ & -3.26 & $-3.41^{* * *}$ \\
\hline $\mathrm{Emp}_{\mathrm{B}} \mathrm{S}_{\mathrm{B}} \mathrm{GR}$ & $-2.84^{*}$ & -2.93 & $-3.01^{* * *}$ & $-3.45^{* *}$ & -3.22 & $-3.55^{* * *}$ \\
\hline $\mathrm{Emp}_{-} \mathrm{S}_{\mathrm{L}_{-}} \mathrm{GR}$ & $-4.10^{* * *}$ & $-4.46^{* *}$ & -0.24 & $0.01^{* *}$ & $0.05^{* *}$ & $-7.55^{* * *}$ \\
\hline Emp_S SNT_GR & -1.24 & -2.18 & -0.57 & $-3.00^{*}$ & -3.25 & $-3.10^{* * *}$ \\
\hline Output_S B_GR $_{\text {G }}$ & -2.24 & -2.40 & $-1.73^{*}$ & $-4.25^{* * *}$ & $-4.10^{* *}$ & $-4.39^{* * *}$ \\
\hline Output_S $\mathrm{S}_{-} G \mathrm{GR}$ & $-3.10^{* *}$ & $-3.73^{* *}$ & -1.31 & $-3.55^{* *}$ & $-3.39^{*}$ & $-5.69^{* * *}$ \\
\hline Output_S NT_GR $_{\text {G }}$ & -1.68 & -2.57 & -1.31 & $-3.61^{* *}$ & $-3.54^{*}$ & $-3.74^{* * *}$ \\
\hline Income_AZN & -2.01 & -2.42 & -1.02 & $-3.83^{* *}$ & $-3.85^{* *}$ & $-3.99^{* * *}$ \\
\hline Income_USD & -1.66 & -2.50 & -1.29 & $-3.44^{* *}$ & $-3.55^{*}$ & $-3.57^{* * *}$ \\
\hline CPI_GR & $-6.57^{* * *}$ & $-6.44^{* * *}$ & $-6.70^{* * *}$ & $-4.94^{* * *}$ & $-4.71^{* *}$ & $-5.15^{* * *}$ \\
\hline MPC_GR & $-3.95^{* * *}$ & -2.97 & $-4.00^{* * *}$ & $-7.87^{* * *}$ & $-7.74^{* * *}$ & $-8.14^{* * *}$ \\
\hline $\begin{array}{l}\text { Gov.spendings } \\
\text { in bil. USD }\end{array}$ & -1.94 & -2.50 & -1.64 & $-4.46^{* * *}$ & $-4.42^{* *}$ & $-4.62^{* * *}$ \\
\hline $\begin{array}{l}\text { Gov.spendings } \\
\text { as } \% \text { of GDP }\end{array}$ & $-4.37^{* * *}$ & $-4.26^{* *}$ & $-4.48^{* * *}$ & $06.96^{* * *}$ & $-6.90^{* * *}$ & $-7.20^{* * *}$ \\
\hline
\end{tabular}

Note: $\mathrm{H}_{0}$ is rejected at the ${ }^{* * *} 1 \% ;{ }^{* *} 5 \%$, and ${ }^{*} 10 \%$ significance level; Lag length based on SIC (Schwarz Information Criterion). 
Phillips - Perron unit root test results

Table A2.

\begin{tabular}{|c|c|c|c|c|c|c|}
\hline \multirow[t]{2}{*}{ Variable } & \multicolumn{3}{|c|}{ Level } & \multicolumn{3}{|c|}{$1^{\text {st }}$ difference } \\
\hline & Intercept & $\begin{array}{l}\text { Intercept } \\
\text { and Trend }\end{array}$ & $\begin{array}{l}\text { Without } \\
\text { Intercept } \\
\text { and Trend }\end{array}$ & Intercept & $\begin{array}{l}\text { Intercept } \\
\text { and Trend }\end{array}$ & $\begin{array}{l}\text { Without } \\
\text { Intercept } \\
\text { and Trend }\end{array}$ \\
\hline Oil_p_GR & $-3.08^{* *}$ & -3.06 & $-2.80^{* * *}$ & $-6.37^{* * *}$ & $-6.07^{* * *}$ & $-6.83^{* * *}$ \\
\hline REER & -1.38 & -1.34 & -0.32 & $-3.32^{* *}$ & -3.23 & $-3.43^{* * *}$ \\
\hline NEER & -1.25 & -1.34 & -0.83 & $-3.36^{* *}$ & -3.19 & $-3.36^{* * *}$ \\
\hline $\mathrm{Emp}_{-} \mathrm{S}_{\mathrm{B}_{-}} \mathrm{GR}$ & $-2.84^{*}$ & -3.03 & $-3.01^{* * *}$ & $-3.42^{* *}$ & -3.25 & $-3.53^{* * *}$ \\
\hline $\mathrm{Emp}_{-} \mathrm{S}_{\mathrm{L}_{-}} \mathrm{GR}$ & $-4.10^{* * *}$ & $-4.46^{* *}$ & -0.81 & $-19.00^{* * *}$ & $-18.09^{* * *}$ & $-14.07^{* * *}$ \\
\hline Emp_SNT_GR & -1.56 & -0.74 & -0.62 & $-2.99^{*}$ & -3.24 & $-3.09^{* * *}$ \\
\hline Output_S $\mathrm{S}_{B_{-}} \mathrm{GR}$ & -2.24 & -2.43 & $-1.73^{*}$ & $-4.33^{* * *}$ & $-4.17^{* *}$ & $-4.50^{* * *}$ \\
\hline Output_S $\mathrm{L}_{-} \mathrm{GR}$ & $-3.10^{* *}$ & $-3.91^{* *}$ & -1.12 & $-10.19^{* * *}$ & $-10.50^{* * *}$ & $-10.46^{* * *}$ \\
\hline Output_S NT_GR $_{\text {G }}$ & -1.68 & -1.98 & -1.37 & $-3.60^{* *}$ & $-3.56^{*}$ & $-3.76^{* * *}$ \\
\hline Income_AZN & -2.04 & -2.46 & -0.93 & $-5.76^{* * *}$ & $-5.72^{* * *}$ & $-5.48^{* * *}$ \\
\hline Income_USD & -1.80 & -2.04 & -1.34 & $-2.23^{* *}$ & -2.98 & $-3.38^{* * *}$ \\
\hline CPI_GR & $-6.57^{* * *}$ & $-649^{* * *}$ & $-6.70^{* * *}$ & $-28.09^{* * *}$ & $-27.67^{* * *}$ & $-27.90^{* * *}$ \\
\hline MPC_GR & $-3.98^{* * *}$ & $-3.89^{* * *}$ & $-4.03^{* * *}$ & $-8.94^{* * *}$ & $-10.33^{* * *}$ & $-9.29^{* * *}$ \\
\hline $\begin{array}{l}\text { Gov.spendings } \\
\text { in bil. USD }\end{array}$ & -1.94 & -2.38 & -1.62 & $-4.57^{* * *}$ & $-4.77^{* * *}$ & $-4.57^{* * *}$ \\
\hline $\begin{array}{l}\text { Gov.spendings } \\
\text { as } \% \text { of GDP }\end{array}$ & $-4.37^{* * *}$ & $-4.28^{* *}$ & $-4.49^{* * *}$ & $-10.18^{* * *}$ & $-14.82^{* * *}$ & $-10.64^{* * *}$ \\
\hline
\end{tabular}

Note: $\mathrm{H}_{0}$ is rejected at the ${ }^{* * *} 1 \%,{ }^{* *} 5 \%$, and ${ }^{*} 10 \%$ significance level; Lag length based on SIC (Schwarz Information Criterion). 
Results of Ramsey reset test and variance inflation factors

Table A3.

\begin{tabular}{l|c|ccc}
\hline Model No. & Variance Inflation Factor & \multicolumn{3}{c}{ Ramsey Reset test Results } \\
\cline { 3 - 5 } & (centered) -<10.00 & t-statistic & F-statistic & Likelihood Ratio \\
\hline 1 & + & $0.14[0.89]$ & $0.02[0.89]$ & $0.03[0.87]$ \\
2 & + & $0.15[0.88]$ & $0.02[0.88]$ & $0.03[0.85]$ \\
3 & + & $0.35[0.74]$ & $0.12[0.74]$ & $0.17[0.68]$ \\
4 & + & $0.39[0.70]$ & $0.15[0.70]$ & $0.21[0.65]$ \\
5 & + & $2.61[0.02]$ & $6.81[0.02]$ & $7.64[0.01]$ \\
6 & + & $2.35[0.04]$ & $5.53[0.04]$ & $6.45[0.01]$ \\
7 & + & $0.46[0.65]$ & $0.22[0.65]$ & $0.30[0.58]$ \\
8 & + & $0.46[0.65]$ & $0.21[0.65]$ & $0.30[0.58]$ \\
9 & + & $0.46[0.66]$ & $0.21[0.66]$ & $0.29[0.66]$ \\
10 & + & $0.53[0.60]$ & $0.28[0.60]$ & $0.40[0.53]$ \\
11 & + & $0.81[0.43]$ & $0.65[0.43]$ & $0.90[0.34]$ \\
12 & + & $0.55[0.59]$ & $0.30[0.59]$ & $0.42[0.52]$ \\
13 & + & $0.85[0.41]$ & $0.73[0.41]$ & $1.00[0.32]$ \\
14 & + & $0.51[0.62]$ & $0.26[0.62]$ & $0.37[0.54]$ \\
15 & + & $0.25[0.81]$ & $0.06[0.81]$ & $0.09[0.77]$ \\
16 & + & $1.08[0.30]$ & $1.18[0.30]$ & $1.57[0.20]$ \\
17 & + & $0.16[0.87]$ & $0.03[0.87]$ & $0.04[0.85]$ \\
18 & + & $0.25[0.81]$ & $0.06[0.81]$ & $0.09[0.77]$ \\
19 & + & $1.59[0.16]$ & $2.53[0.16]$ & $3.86[0.05]$ \\
20 & + & $1.24[0.26]$ & $1.54[0.26]$ & $2.52[0.11]$ \\
21 & + & $0.22[0.83]$ & $0.05[0.83]$ & $0.09[0.76]$ \\
22 & + & $0.03[0.97]$ & $0.00[0.97]$ & $0.00[0.96]$ \\
23 & + & $0.71[0.50]$ & $0.50[0.50]$ & $0.89[0.34]$ \\
24 & + & $0.57[0.59]$ & $0.32[0.59]$ & $0.58[0.49]$ \\
25 & + & $0.27[0.79]$ & $0.07[0.79]$ & $0.10[0.75]$ \\
26 & + & $0.07[0.94]$ & $0.01[0.94]$ & $0.01[0.93]$ \\
27 & + & $0.06[0.96]$ & $0.00[0.96]$ & $0.00[0.95]$ \\
28 & + & $1.65[0.22]$ & $2.19[0.14]$ \\
& + & &
\end{tabular}




\begin{tabular}{c|c|ccc}
\multicolumn{1}{c}{} & \multicolumn{3}{c}{ Continues } \\
\hline Model No. & Variance Inflation Factor & \multicolumn{3}{c}{ Ramsey Reset test Results } \\
\cline { 3 - 5 } & (centered) $-<10.00$ & t-statistic & F-statistic & Likelihood Ratio \\
\hline 29 & + & $1.40[0.19]$ & $1.96[0.19]$ & $2.57[0.11]$ \\
30 & + & $0.22[0.83]$ & $0.05[0.83]$ & $0.07[0.80]$ \\
31 & + & $0.55[0.59]$ & $0.30[0.59]$ & $0.42[0.52]$ \\
32 & + & $0.69[0.50]$ & $0.47[0.50]$ & $0.66[0.42]$ \\
33 & + & $1.26[0.23]$ & $1.59[0.23]$ & $2.11[0.15]$ \\
34 & + & $0.77[0.46]$ & $0.59[0.46]$ & $0.82[0.37]$ \\
35 & + & $1.32[0.21]$ & $1.74[0.21]$ & $2.31[0.13]$ \\
36 & + & $2.48[0.03]$ & $6.15[0.03]$ & $7.03[0.01]$ \\
37 & + & $0.20[0.85]$ & $0.04[0.85]$ & $0.06[0.81]$ \\
38 & + & $0.62[0.55]$ & $0.38[0.55]$ & $0.58[0.45]$ \\
39 & + & $0.14[0.89]$ & $0.02[0.89]$ & $0.03[0.86]$ \\
40 & + & $0.55[0.60]$ & $0.30[0.60]$ & $0.45[0.50]$ \\
41 & + & $0.81[0.43]$ & $0.66[0.43]$ & $0.99[0.32]$ \\
42 & + & $1.19[0.26]$ & $1.42[0.26]$ & $2.06[0.15]$ \\
\hline \hline
\end{tabular}

Note: $p$-values are inside the brackets. 
Pairwise Granger causality tests for sectoral disribution

Table A4.

\section{of the impact of oil prices, REER, NEER and economic crisis}

Sample: 2000-2018

Lags: 2

\begin{tabular}{|c|c|c|c|}
\hline & Obs & F-Statistic & Prob. \\
\hline \multicolumn{4}{|l|}{ Null Hypothesis: } \\
\hline S $_{\text {B }}$ utput does not Granger Cause REER & 15 & 0.37506 & 0.6965 \\
\hline REER does not Granger Cause $S_{\text {в }}$ output & & 2.47224 & 0.1342 \\
\hline$S_{\mathrm{L}}$ output does not Granger Cause REER & 15 & 0.29412 & 0.7514 \\
\hline REER does not Granger Cause $S_{L}$ output & & 2.99280 & 0.0958 \\
\hline $\mathrm{S}_{\mathrm{NT}}$ output does not Granger Cause REER & 15 & 0.10379 & 0.9024 \\
\hline REER does not Granger Cause $S_{\mathrm{NT}}$ output & & 7.04786 & 0.0123 \\
\hline Oil price changes does not Granger Cause REER & 15 & 0.21197 & 0.8125 \\
\hline REER does not Granger Cause Oil price changes & & 7.05477 & 0.0123 \\
\hline$S_{L}$ output does not Granger Cause $S_{B}$ output & 15 & 0.93081 & 0.4259 \\
\hline$S_{B}$ output does not Granger Cause $S_{L}$ output & & 3.12544 & 0.0882 \\
\hline $\mathrm{S}_{\mathrm{NT}}$ output does not Granger Cause $\mathrm{S}_{\mathrm{B}}$ output & 15 & 4.04015 & 0.0518 \\
\hline $\mathrm{S}_{\mathrm{B}}$ output does not Granger Cause $\mathrm{S}_{\mathrm{NT}}$ output & & 2.66614 & 0.1180 \\
\hline Oil price changes does not Granger Cause $S_{B}$ output & 15 & 0.87670 & 0.4458 \\
\hline$S_{B}$ output does not Granger Cause Oil price changes & & 0.14523 & 0.8666 \\
\hline $\mathrm{S}_{\mathrm{NT}}$ output does not Granger Cause $\mathrm{S}_{\mathrm{L}}$ output & 15 & 0.50301 & 0.6192 \\
\hline$S_{\mathrm{L}}$ output does not Granger Cause $\mathrm{S}_{\mathrm{NT}}$ output & & 0.77996 & 0.4844 \\
\hline Oil price changes does not Granger Cause $\mathrm{S}_{\mathrm{L}}$ output & 15 & 0.00949 & 0.9906 \\
\hline SL output does not Granger Cause Oil price changes & & 0.46289 & 0.6423 \\
\hline Oil price changes does not Granger Cause $\mathrm{S}_{\mathrm{NT}}$ output & 15 & 0.12853 & 0.8808 \\
\hline $\mathrm{S}_{\mathrm{NT}}$ output does not Granger Cause Oil price changes & & 0.92008 & 0.4297 \\
\hline
\end{tabular}


Pairwise Granger causality tests for resource movement effect

Table A5.

Sample: $2000-2018$

Lags: 2

\begin{tabular}{|c|c|c|c|}
\hline & Obs & F-Statistic & Prob. \\
\hline \multicolumn{4}{|l|}{ Null Hypothesis: } \\
\hline$S_{L}$ Output does not Granger Cause $S_{B}$ Output & 15 & 0.93081 & 0.4259 \\
\hline $\mathrm{S}_{\mathrm{B}}$ Output does not Granger Cause $\mathrm{S}_{\mathrm{L}}$ Output & & 3.12544 & 0.0882 \\
\hline $\mathrm{S}_{\mathrm{NT}}$ Output does not Granger Cause $\mathrm{S}_{\mathrm{B}}$ Output & 15 & 4.04015 & 0.0518 \\
\hline $\mathrm{S}_{\mathrm{B}}$ Output does not Granger Cause $\mathrm{S}_{\mathrm{NT}}$ Output & & 2.66614 & 0.1180 \\
\hline $\mathrm{S}_{\mathrm{B}}$ Employment does not Granger Cause $\mathrm{S}_{\mathrm{B}}$ Output & 15 & 1.63834 & 0.2424 \\
\hline$S_{B}$ Output does not Granger Cause $S_{B}$ Employment & & 1.10605 & 0.3682 \\
\hline$S_{\mathrm{L}}$ Employment does not Granger Cause $S_{B}$ Output & 15 & 0.06533 & 0.9372 \\
\hline$S_{B}$ Output does not Granger Cause $S_{L}$ Employment & & 0.27167 & 0.7676 \\
\hline $\mathrm{S}_{\mathrm{NT}}$ Employment does not Granger Cause $\mathrm{S}_{\mathrm{B}}$ Output & 15 & 0.73710 & 0.5028 \\
\hline $\mathrm{S}_{\mathrm{B}}$ Output does not Granger Cause $\mathrm{S}_{\mathrm{NT}}$ Employment & & 0.77932 & 0.4847 \\
\hline Income of population in USD does not Granger Cause $S_{B}$ Output & 15 & 2.50705 & 0.1311 \\
\hline $\mathrm{S}_{\mathrm{B}}$ Output does not Granger Cause Income of population in USD & & 2.62172 & 0.1215 \\
\hline $\mathrm{S}_{\mathrm{NT}}$ Output does not Granger Cause $\mathrm{S}_{\mathrm{L}}$ Output & 15 & 0.50301 & 0.6192 \\
\hline$S_{\mathrm{L}}$ Output does not Granger Cause $\mathrm{S}_{\mathrm{NT}}$ Output & & 0.77996 & 0.4844 \\
\hline $\mathrm{S}_{\mathrm{B}}$ Employment does not Granger Cause $\mathrm{S}_{\mathrm{L}}$ Output & 15 & 0.06343 & 0.9389 \\
\hline$S_{L}$ Output does not Granger Cause $S_{B}$ Employment & & 0.59436 & 0.5703 \\
\hline $\mathrm{S}_{\mathrm{L}}$ Employment does not Granger Cause $\mathrm{S}_{\mathrm{L}}$ Output & 15 & 0.02614 & 0.9743 \\
\hline$S_{L}$ Outputdoes not Granger Cause $S_{L}$ Employment & & 1.03962 & 0.3889 \\
\hline S $_{\mathrm{NT}}$ Employmentdoes not Granger Cause $\mathrm{S}_{\mathrm{L}}$ Output & 15 & 0.33889 & 0.7204 \\
\hline $\mathrm{S}_{\mathrm{L}}$ Outputdoes not Granger Cause $\mathrm{S}_{\mathrm{NT}}$ Employment & & 0.95807 & 0.4162 \\
\hline Income of population in USD does not Granger Cause $S_{L}$ Output & 15 & 0.89636 & 0.4385 \\
\hline$S_{\mathrm{L}}$ Outputdoes not Granger Cause Income of population in USD & & 0.14207 & 0.8693 \\
\hline S $_{B}$ Employment does not Granger Cause $S_{\mathrm{NT}}$ Output & 15 & 0.36296 & 0.7044 \\
\hline S $_{\mathrm{NT}}$ Output does not Granger Cause $S_{B}$ Employment & & 0.82421 & 0.4663 \\
\hline $\mathrm{S}_{\mathrm{L}}$ Employment does not Granger Cause $\mathrm{S}_{\mathrm{NT}}$ Output & 15 & 1.91279 & 0.1980 \\
\hline $\mathrm{S}_{\mathrm{NT}}$ Output does not Granger Cause $\mathrm{S}_{\mathrm{L}}$ Employment & & 2.04080 & 0.1806 \\
\hline
\end{tabular}




\begin{tabular}{|c|c|c|c|}
\hline & Obs & F-Statistic & Prob. \\
\hline $\mathrm{S}_{\mathrm{NT}}$ Employment does not Granger Cause $\mathrm{S}_{\mathrm{NT}}$ Output & 15 & 2.74819 & 0.1119 \\
\hline $\mathrm{S}_{\mathrm{NT}}$ Output does not Granger Cause $\mathrm{S}_{\mathrm{NT}}$ Employment & & 2.05793 & 0.1784 \\
\hline Income of population in USD does not Granger Cause $\mathrm{S}_{\mathrm{NT}}$ Output & 15 & 1.55118 & 0.2590 \\
\hline $\mathrm{S}_{\mathrm{NT}}$ Output does not Granger Cause Income of population in USD & & 0.10943 & 0.8974 \\
\hline$S_{L}$ Employment does not Granger Cause $S_{B}$ Employment & 15 & 0.93782 & 0.4234 \\
\hline $\mathrm{S}_{\mathrm{B}}$ Employment does not Granger Cause $\mathrm{S}_{\mathrm{L}}$ Employment & & 0.60763 & 0.5636 \\
\hline $\mathrm{S}_{\mathrm{NT}}$ Employment does not Granger Cause $\mathrm{S}_{\mathrm{B}}$ Employment & 15 & 6.61383 & 0.0148 \\
\hline $\mathrm{S}_{\mathrm{B}}$ Employment does not Granger Cause $\mathrm{S}_{\mathrm{NT}}$ Employment & & 2.20292 & 0.1612 \\
\hline Income of population in USD does not Granger Cause $S_{B}$ Employment & 15 & 1.89214 & 0.2009 \\
\hline$S_{\text {В }}$ Employment does not Granger Cause Income of population in USD & & 0.78717 & 0.4814 \\
\hline $\mathrm{S}_{\mathrm{NT}}$ Employment does not Granger Cause $\mathrm{S}_{\mathrm{L}}$ Employment & 15 & 0.09518 & 0.9100 \\
\hline $\mathrm{S}_{\mathrm{L}}$ Employment does not Granger Cause $\mathrm{S}_{\mathrm{NT}}$ Employment & & 0.75422 & 0.4954 \\
\hline Income of population in USD does not Granger Cause $S_{L}$ Employment & 15 & 2.67620 & 0.1173 \\
\hline $\mathrm{S}_{\mathrm{L}}$ Employment does not Granger Cause Income of population in USD & & 1.06251 & 0.3816 \\
\hline Income of population in USD does not Granger Cause $S_{\mathrm{NT}}$ Employment & 15 & 2.25735 & 0.1552 \\
\hline 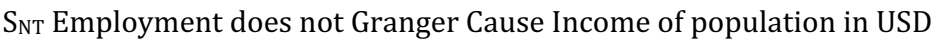 & & 1.42494 & 0.2854 \\
\hline
\end{tabular}


Pairwise Granger causality tests for spending effect

Table A6.

Sample: $2000-2018$

Lags: 2

\begin{tabular}{|c|c|c|c|}
\hline & Obs & F-Statistic & Prob. \\
\hline \multicolumn{4}{|l|}{ Null Hypothesis: } \\
\hline MPC does not Granger Cause CPI & 15 & 0.75378 & 0.4955 \\
\hline CPI does not Granger Cause MPC & & 4.36802 & 0.0433 \\
\hline REER does not Granger Cause CPI & 15 & 1.91912 & 0.1971 \\
\hline CPI does not Granger Cause REER & & 1.43427 & 0.2834 \\
\hline $\mathrm{S}_{\mathrm{NT}}$ Output does not Granger Cause CPI & 15 & 0.49545 & 0.6235 \\
\hline CPI does not Granger Cause $\mathrm{S}_{\mathrm{NT}}$ Output & & 3.60360 & 0.0663 \\
\hline Government Spendings in billion USD does not Granger Cause CPI & 15 & 0.78952 & 0.4804 \\
\hline CPI does not Granger Cause Government Spendings in Billion USD & & 2.44786 & 0.1364 \\
\hline Government Spendings \% of GDP does not Granger Cause CPI & 15 & 0.05695 & 0.9449 \\
\hline CPI does not Granger Cause Government Spendings \% of GDP & & 9.06858 & 0.0057 \\
\hline Income of population in USD does not Granger Cause CPI & 15 & 0.56081 & 0.5877 \\
\hline CPI does not Granger Cause Income of population in US & & 1.26265 & 0.3244 \\
\hline REER does not Granger Cause MPC & 15 & 1.59284 & 0.2509 \\
\hline MPC does not Granger Cause REER & & 0.10434 & 0.9019 \\
\hline $\mathrm{S}_{\mathrm{NT}}$ Output does not Granger Cause MPC & 15 & 1.10623 & 0.3681 \\
\hline MPC does not Granger Cause $\mathrm{S}_{\mathrm{NT}}$ Output & & 0.19552 & 0.8255 \\
\hline Government Spendings in billion USD does not Granger Cause MPC & 15 & 3.06212 & 0.0917 \\
\hline MPC does not Granger Cause Government Spendings in Billion USD & & 0.11715 & 0.8907 \\
\hline Government Spendings \% of GDP does not Granger Cause MPC & 15 & 1.09765 & 0.3707 \\
\hline MPC does not Granger Cause Government Spendings \% of GDP & & 1.00654 & 0.3997 \\
\hline Income of population in USD does not Granger Cause MPC & 15 & 1.93602 & 0.1947 \\
\hline MPC does not Granger Cause Income of population in USD & & 0.02058 & 0.9797 \\
\hline SNT $_{\mathrm{NT}}$ Output does not Granger Cause REER & 15 & 2.37094 & 0.1436 \\
\hline REER does not Granger Cause $S_{\mathrm{NT}}$ Output & & 0.88186 & 0.4439 \\
\hline Government Spendings in billion USD does not Granger Cause REER & 15 & 5.83059 & 0.0210 \\
\hline REER does not Granger Cause Government Spendings in Billion USD & & 0.12856 & 0.8808 \\
\hline
\end{tabular}




\begin{tabular}{|c|c|c|c|}
\hline & & & Continues \\
\hline & Obs & F-Statistic & Prob. \\
\hline Government Spendings \% of GDP does not Granger Cause REER & 15 & 1.61558 & 0.2466 \\
\hline REER does not Granger Cause Government Spendings \% of GDP & & 1.35566 & 0.3013 \\
\hline Income of population in USD does not Granger Cause REER & 15 & 2.47138 & 0.1342 \\
\hline REER does not Granger Cause Income of population in USD & & 2.80328 & 0.1080 \\
\hline Government Spendings in billion USD does not Granger Cause S $_{\mathrm{NT}}$ Output & 15 & 3.22183 & 0.0832 \\
\hline $\mathrm{S}_{\mathrm{NT}}$ Output does not Granger Cause Government Spendings in Billion USD & & 3.17998 & 0.0853 \\
\hline Government Spendings \% of GDP does not Granger Cause $\mathrm{S}_{\mathrm{NT}}$ Output & 15 & 0.13987 & 0.8711 \\
\hline $\mathrm{S}_{\mathrm{NT}}$ Output does not Granger Cause Government Spendings \% of GDP & & 1.42957 & 0.2844 \\
\hline Income of population in USD does not Granger Cause $S_{\mathrm{NT}}$ Output & 15 & 1.55118 & 0.2590 \\
\hline S $_{\mathrm{NT}}$ Output does not Granger Cause Income of population in USD & & 0.10943 & 0.8974 \\
\hline $\begin{array}{l}\text { Government Spendings \% Of GDP does not Granger Cause Government } \\
\text { Spendings in Billion USD }\end{array}$ & 15 & 2.44123 & 0.1370 \\
\hline $\begin{array}{l}\text { Government Spendings in billion USD does not Granger Cause } \\
\text { Government Spendings \% of GDP }\end{array}$ & & 3.67785 & 0.0635 \\
\hline $\begin{array}{l}\text { Income of population in USD does not Granger Cause Government } \\
\text { Spendings in Billion USD }\end{array}$ & 15 & 1.50811 & 0.2677 \\
\hline $\begin{array}{l}\text { Government spendings in billion USD does not Granger Cause Income } \\
\text { of population in USD }\end{array}$ & & 2.56180 & 0.1264 \\
\hline $\begin{array}{l}\text { Income of population in USD does not Granger Cause Government } \\
\text { Spendings \% of GDP }\end{array}$ & 15 & 5.00053 & 0.0312 \\
\hline $\begin{array}{l}\text { Government Spendings \% of Gdp does not Granger Cause Income } \\
\text { of population in USD }\end{array}$ & & 1.06121 & 0.3820 \\
\hline
\end{tabular}

$$
\begin{gathered}
* * \\
*
\end{gathered}
$$

\section{References}

Ağazade S. (2018) Reel Döviz Kuru ve Petrol Fiyatlari İlişkisinde Asimetri: Azerbaycan Örneğinde Bir İnceleme [Asymmetry in the Relationship between Real Exchange Rate and Oil Prices: An Analysis for Azerbaijan]. International Journal of Economics and Administrative Studies, Special Issue, pp. 113-126.

Aliyev K., Dehning B., Nadirov 0. (2016) Modelling the Impact of Fiscal Policy on Non-Oil GDP in a Resource Rich Country: Evidence from Azerbaijan. Acta Universitatis Agriculturae et Silviculturae Mendelianae Brunensis, 64, 6, pp. 1869-1878. 

Routledge.

Auty R.M. (1993) Sustaining Development in Mineral Economies: The Resource Curse Thesis. London:

Auty R.M. (1998) Resource Abundance and Economic Development: Improving the Performance of Resource-Rich Countries. Helsinki, Finland: UNU World Institute for Development Economics Research. Working Paper 44/1998.

Bahmani-Oskooee M., Jamilov R. (2014) Export Diversification and the S-curve Effect in a ResourceRich State: Evidence from Azerbaijan. Economic Change and Restructuring, 47, 2, pp. 135-154.

Bayramov G., Conway P. (2010) The Azerbaijan Producers Survey: Dutch Disease and Financial Crisis. Baku, Azerbaijan: Economic Research Center, July. Available at: http://www.erc.az/files/reports/Bayramov Conway_Azerbaijan.pdf (accessed: 11.06.2020).

Belsley D.A., Kuh E., Welsch R. E. (1980) Regression Diagnostics: Identifying Influential Data and Sources of Collinearity. New York: John Wiley \& Sons, Ltd.

Brahmbhatt M., Canuto O.,Vostroknutova E. (2010) Dealing with Dutch Disease. Economic Premise, World Bank, 16, pp. 1-7.

British Petroleum Company (2018) BP Statistical Review of World Energy. 67th ed. Available at: https://www.bp.com/content/dam/bp/en/corporate/pdf/energy-economics/statistical-review/bp-statsreview-2018-full-report.pdf (accessed: 01.06.2020)

Bulut C., Suleymanov E. (2012) Azerbaycanin Hollanda Hastaliği Problemini Önleme Stratejilerinde Türkiye Ile Yapilan Ekonomik Ilişkilerin Önemi [Importance of Economic Collaboration between Azerbaijan and Turkey in Preventing Dutch Disease in Azerbaijan]. International Symposium on Regional Cooperation and Development. Erzurum: Erzurum Ataturk University Culture and Performance Center.

Central Bank of the Republic of Azerbaijan - CBAR (2020) Nominal and Real Effective Exchange Rates of Manat to Foreign Currencies. Available at: https://uploads.cbar.az/assets/0c361200c 8f13f2f219 af66d9.xlsx (accessed: 02.06.2020).

Corden W.M. (1984) Booming Sector and Dutch Disease Economics: Survey and Consolidation. OXford Economic Papers, 36, 3, pp. 359-380.

Corden W.M. (2012) Dutch Disease in Australia: Policy Options for a Three-Speed Economy. The Australian Economic Review, 45, 3, pp. 290-304.

Corden W.M., Neary J.P (1982) Booming Sector and De-Industrialisation in a Small Open Economy. The Economic Journal, 92, 368, pp. 825-848.

Czech K. (2018) Oil Dependence of Post-Soviet Countries in the Caspian Sea Region: The Case of Azerbaijan and Kazakhstan. Acta Scientiarum Polonorum. Oeconomia, 17, 3, pp. 5-12.

De Broeck M., Sløk T. (2001) Interpreting Real Exchange Rate Movements in Transition Countries. IMF Working Paper WP/01/56.

Dickey D.A., Fuller W.A. (1981) Likelihood Ratio Statistics for Autoregressive Time Series with a Unit Root. Econometrica, 49, 4, pp. 1057-1072.

Dikkaya M., Doyar B.V. (2017) Causality Among Oil Prices, GDP and Exchange Rate: Evidence from Azerbaijan and Kazakhstan, Bilig, 83, pp. 79-98.

Egert B. (2012) Dutch Disease in the Post-Soviet Countries of Central and South-West Asia: How Contagious Is It? Journal of Asian Economics, 23, 5, pp. 571-584.

Falkowski K. (2018) The Importance of Energy Resources for Azerbaijan's International Competitiveness. Journal of International Studies, 11, 4, pp. 44-56.

Fardmanesh M. (1991) Dutch Disease Economics and Oil Syndrome: An Empirical Study. World Development, 19, 6, pp. 711-717.

Freund R.J., Littell R.C., Creighton L. (2003) Regression Using JMP. John Wiley \& Sons, Inc.

Gahramanov E.F., Fan L.-S. (2002) The «Dutch Disease» in Caspian Region: The Case of Azerbaijan Republic. Economic Studies, 5, 10, pp. 9-30.

Gasimov I. (2014) Resource Curse and Dutch Disease in Azerbaijan: Empirical Analysis. Doctoral dissertation, Eastern Mediterranean University (EMU)-Doğu Akdeniz Üniversitesi (DAÜ).

Gojayev V. (2010) Resource Nationalism Trends in Azerbaijan, 2004-2009. RUSSCASP Working Paper. Oslo: Research Council of Norway, Fridtjof Nansen Institute, Norwegian Institute of International Affairs, Econ Pöyry. 
Granger C.W.J. (1969) Investigating Causal Relations by Econometric Models and Cross-spectral Methods. Econometrica, 37, 3, pp. 424-438.

Gylfason T. (2001) Lessons from the Dutch Disease: Causes, Treatment, and Cures. Institute of Economic Studies. Working Paper Series W01:06. University of Iceland.

Hasanov F. (2010) The Impact Of Real Oil Price On Real Effective Exchange Rate: The Case of Azerbaijan. German Institute for Economic Research (DIW) Discussion Paper, no 1041.

Hasanov F. (2013) Dutch Disease and the Azerbaijan Economy. Communist and Post-Communist Studies, 46, 4, pp. 463-480.

Hasanov F., Samadova I. (2010) The Impact of Real Exchange Rate on Non-Oil Exports: The Case of Azerbaijan. MPRA Paper, no 29556.

Hausmann R., Hwang J., Rodrik D. (2007) What You Export Matters. Journal of Economic Growth, 12,1 , pp. $1-25$

Hayat A., Ganiev B., Tang X. (2013) Expectations of Future Income and Real Exchange Rate Movements. Journal of Banking \& Finance, 37, 4, pp. 1274-1285.

Huseynov S. (2009) Monetary Policy and Inflation Dynamics in Azerbaijan. Doctoral dissertation, Central European University.

Huseynov N. (2017) Approach to the Azerbaijan Economic Structure: Non-Oil Sector. North Economic Review, 1, 1, pp. 28-40.

Hutcheson G.D., Sofroniou N. (1999) The Multivariate Social Scientist: Introductory Statistics Using Generalized Linear Models. London: SAGE Publications.

Ibadoglu G. (2008) Current State of Azerbaijan's Economy: Myths and Realities. Transition Studies Review, 15, 2, pp. 425-430.

Indexmundi (2020) Commodity Prices - Oil Prices (BRENT trademark). Available at: https://www.indexmundi.com/commodities (accessed: 05.05.2020).

Kaser M. (2003) The Economic and Social Impact of Systemic Transition in Central Asia and Azerbaijan. Perspectives on Global Development and Technology, 2, 3, pp. 459-473.

Koeda J., Kramarenko V. (2008) Impact of Government Expenditure on Growth: The Case of Azerbaijan. IMF Working Paper WP/08/115, pp. 1-18.

Krugman P. (1987) The Narrow Moving Band, the Dutch Disease, and the Competitive Consequences of Mrs. Thatcher: Notes on Trade in the Presence of Dynamic Scale Economies. Journal of Development Economics, 27, 1-2, pp. 41-55.

Lucas Jr.R.E. (1993) Making a Miracle. Econometrica, 61, 2, pp. 251-272.

Magud N., Sosa S. (2013) When and Why Worry about Real Exchange Rate Appreciation? The Missing Link between Dutch Disease and Growth. Journal of International Commerce, Economics and Policy, 4, 2, 1350009.

Mahnovski S. (2003) Natural Resources and Potential Conflict in the Caspian Sea Region. Ch. 5. Faultlines of Conflict in Central Asia and the South Caucasus: Implications for the U.S. Army (eds. O. Oliker, T. Szayna), Santa Monica: RAND Corporation, pp. 109-144.

Matsuyama K. (1992) Agricultural Productivity, Comparative Advantage, and Economic Growth. Journal of Economic Theory, 58, 2, pp. 317-334.

Mehtiyev A. (2018) Foreign Direct Investment in Azerbaijan's Economy: Current Status, Development Trends and Challenges. Baku Research Institute. Available at: https://bakuresearchinstitute.org/foreigndirect-investment-in-azerbaijans-economy-current-status-development-trends-and-challenges/ (accessed: 03.05.2020).

Mironov V.V., Petronevich A.V. (2015) Discovering the Signs of Dutch Disease in Russia. Resources Policy, 46, Part 2, pp. 97-112.

Niftiyev I. (2020) The De-industrialization Process in Azerbaijan: Dutch Disease Syndrome Revisited. Proceedings of the $4^{\text {th }}$ Central European PhD Workshop on Technological Change and Development (ed. B. Udvari). University of Szeged, Doctoral School in Economics, Szeged, pp. 357-396.

Nuri Aras O., Suleymanov E., Mammadov K. (2016) Economy of Azerbaijan: 25 Years of Independence. Baku: Sharg-Garb Publishing House. 
O'Lear S. (2007) Azerbaijan's Resource Wealth: Political Legitimacy and Public Opinion. The Geographical Journal, 173, 3, pp. 207-223.

Phillips P.C.B., Perron P. (1988) Testing for a Unit Root in Time Series Regression. Biometrika, 75, 2, pp. 335-346.

Robinson C., Schumacker R.E. (2009) Interaction Effects: Centering, Variance Inflation Factor, and Interpretation Issues. Multiple Linear Regression Viewpoints, 35, 1, pp. 6-11.

Sabiroglu I.M., Bashirli S. (2012) Input-output Analysis in an Oil-Rich Economy: The Case of Azerbaijan. Resources Policy, 37, 1, pp. 73-80.

Sachs J.D., Warner A.M. (2001) The Curse of Natural Resources. European Economic Review, 45, 46, pp. 827-838.

Sachs J.D., Warner A.M. (1995) Natural Resource Abundance and Economic Growth. NBER Working Paper no 5398. Cambridge MA.

Şanlısoy S., Ekinci R. (2019) Azerbaycan Ekonomisinin Hollanda Hastalı̆̆ı Açısından Değerlendirilmesi. Yönetim ve Ekonomi: Celal Bayar Üniversitesi İktisadi ve İdari Bilimler Fakültesi Dergisi [Journal of Management and Economics], 26, 2, pp. 595-608.

Singh R., Laurila J. (1999) Azerbaijan: Recent Economic Developments and Policy Issues in Sustainability of Growth. Bank of Finland - Institute for Economies in Transition (BOFIT), Discussion Papers no 5/1999.

(SOFAZ) State Oil Fund of The Republic of Azerbaijan (2020) Annual Reports. Available at: https://www.oilfund.az/en/report-and-statistics/report-archive\# (accessed: 23.06.2020)

(SSCRA) State Statistical Committee of the Republic of Azerbaijan (2019) National Account of Azerbaijan. Statistical yearbook. Available at: https://www.stat.gov.az/menu/6/statistical_yearbooks/source/ system_nat_accounts_2019.zip (accessed: 22.06.2020)

SSCRA (2020a) Distribution of Employed Population by Economic Activities (Dynamics). Available at: https://www.stat.gov.az/source/labour/en/002_1-2en.xls (accessed: 22.06.2020)

SSCRA (2020b) Volume of Industrial Products (Works, Services). Available at: https://www.stat.gov.az/ source/industry/en/006en.xls (accessed: 22.06.2020)

SSCRA (2020c) Gross Output of Agriculture. Available at: https://www.stat.gov.az/source/agriculture/ en/1.8en.xls (accessed: 22.06.2020)

SSCRA (2020d) Average Monthly Nominal Wages and Salaries by Economic Activities. Available at: https://www.stat.gov.az/source/labour/en/004_2-3en.xls (accessed: 22.06.2020)

SSCRA (2020f) Investments Directed to Main Capital of Industry. Available at: https://www.stat.gov.az/ source/industry/en/015en.xls (accessed: 22.06.2020)

SSCRA (2020g) Volume of Investment in Fixed by Sectors of Economy. Available at: https://www.stat.gov.az/source/agriculture/en/1.6en.xls (accessed: 22.06.2020)

SSCRA (2020i) Consumer Price Index. Available at: https://www.stat.gov.az/source/price_tarif/ en/001_2en.xlsx (accessed: 22.06.2020)

SSRA (2020e) Production and Generation of Income Account. Available at: https://www.stat.gov.az/ source/system_nat_accounts/en/013en.xls (accessed: 22.06.2020)

Statement of the Central Bank of the Republic of Azerbaijan (2015a) Available at: https://www.cbar.az/ press-release-919/statement-of-the-central-bank-of-the-republic-of-azerbaijan?language=en (accessed: 21.06.2020)

The Economist (1977) The Dutch Disease. The Economist, 26, pp. 82-83.

The Global Economy, World Bank (2020a). Azerbaijan: Government spending, in dollars. Available at: https://www.theglobaleconomy.com/Azerbaijan/government_spending_dollars/ (accessed: 11.06.2020).

The Global Economy, World Bank (2020b). Azerbaijan: Government spending, percent of GDP. Available at: https://www.theglobaleconomy.com/Azerbaijan/Government_size/ (accessed: 11.06.2020). Uçan O., Ünal A. E. (2018) Hollanda Hastalığına Sebep Olabilecek Makroekonomik Etkenler: Seçilmiş Ülke Ekonomileri Üzerine Bir Analiz (Macroeconomic factors that may cause Dutch Disease: an analysis on aelected country economies). $5^{\text {th }}$ International Congress on Political, Economic and Social Studies (ICPESS), Niğde, Proceedings: 2, 2, pp. 376-393. 
Usui N. (2007) How Effective are Oil Funds? Managing Resource Windfalls in Azerbaijan and Kazakhstan. ERD Policy Brief Series no 50, Asian Development Bank.

World Bank (2019a) Oil Rents (\% of GDP) - Azerbaijan, Kazakhstan, Russian Federation, Ukraine, Georgia, Armenia, Turkmenistan, Uzbekistan, Latvia, Estonia, Belarus, Lithuania, Tajikistan, Moldova. Available at: https://data.worldbank.org/indicator/NY.GDP.PETR.RT.ZS?locations=AZ-KZ-RU-UA-GE-AM-TM-UZ-LVEE-BY-LT-TJ-MD (accessed: 11.06.2020).

World Bank (2019e) Oil Rents (\% of GDP). Available at: https://datacatalog.worldbank.org/oilrents-gdp (accessed: 01.06.2020).

World Bank (2019f) GDP per Person Employed (constant 2017 PPP \$) - Azerbaijan. Available at: https://data.worldbank.org/indicator/SL.GDP.PCAP.EM.KD?locations=AZ (accessed: 28.06.2020).

World Bank (2020b) GDP (current US\$) - Azerbaijan. Available at: https://data.worldbank.org/ indicator/NY.GDP.MKTP.CD?locations=AZ (accessed: 15.07.2020).

World Bank (2020c). GDP per Capita (current US\$) - Azerbaijan. Available at: https://data.worldbank.org/indicator/NY.GDP.PCAP.CD?locations=AZ (accessed: 15.05.2020).

World Bank (2020d) GDP per Capita, PPP (current international \$) - Azerbaijan. Available at: https://data.worldbank.org/indicator/NY.GDP.PCAP.PP.CD?locations=AZ (accessed: 11.06.2020).

World Bank (2020g) Services, Value Added (current US\$) - Azerbaijan. Available at: https://data.worldbank.org/indicator/NV.SRV.TOTL.CD?locations=AZ (accessed: 28.06.2020).

World Bank (2020i) Consumer Price Index (2010 = 100) - Azerbaijan. Available at: https://data.worldbank.org/indicator/FP.CPI.TOTL?locations=AZ (accessed: 28.06.2020).

Yun K. (2018) Dutch Disease in Post-Soviet Oil Exporting Countries: Impact of Real Appreciation on De-industrialization. East Asian Community Review, 1, 3-4, pp. 199-219.

Zulfigarov F., Neuenkirch M. (2019) Azerbaijan and Its Oil Resources: Curse or Blessing? Universitat Trier, Research Papers in Economics no 11/19, Available at: https://www.econstor.eu/bitstream/10419/ 207043/1/1667010700.pdf (accessed on 10.05.2020). 